\title{
2011 年東北地方太平洋沖地震における強震動生成域からの長周期地震動
}

\author{
倉橋奨 ${ }^{1)}$ ，入倉孝次郎 ${ }^{2}$
}

1) 正会員 前 愛知工業大学 地域防災研究センター, 客員講師 博士（工学）

現 愛知工業大学, 講師

e-mail : susumu@ aitech.ac.jp

2) 正会員 愛知工業大学 地域防災研究センター, 客員教授 理学博士

e-mail : irikura@geor.or.jp

\section{要 約}

本研究は, 海溝型巨大地震を対象とした, 超高層ビルなどの長周期構造物の被害に影響す る長周期地震動（2－10秒）のための震源モデルおよび評価手法の構築を目的としている. 2011年東北地方太平洋沖地震（以下 2011年東北地震と呼ぶ）の短周期地震動を生成した SMGA（強震動生成域）からの波群の地震動の解析により, それらの震源スペクトルは, 2 - 10秒の長周期帯域を含んで $\omega^{-2}$ 則に従う特性を持っていることがわかった。 すなわち, SMGAからの地震動は, SMGAの直径に対応寸るコーナー周波数をもち, それよりも高周 波数でほぼ $\omega^{-2} て ゙$ 減衰する. 理論的グリーン関数を用いて, SMGAからの地震動を計算する には, SMGAを分割する小断層サイズおよびすべり速度関数の適切な選択が必要とされる. ここでは，すべり速度関数として smoothed ramp関数と中村・宮武（2000）の関数を用いて 比較検討を行った．小断層サイズを小さくすると，指向性効果などの破壊伝播の再現がよ り有効になるという利点があるが, 小さくしすぎると, どちらの関数を用いても高周波数

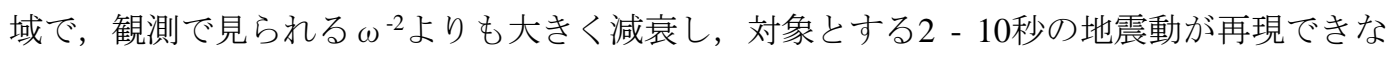
い. 同じ小断層サイズの時, ライズタイムの逆数の周波数よりも高周波数域では，中村・ 宮武（2000）の関数に比べて smoothed ramp関数はより大きく減衰する. 中村・宮武 (2000) の関数を用いて，小断層を $1 \times 1 \mathrm{~km}^{2}$ とし，破壊伝播速度に $10 \%$ の摇らぎを与えることによ り, 強震動生成域からの地震動は周期1秒までほぼ $\omega^{-2}$ の特性をもつことを確認した。 上記 のすべり時間関数, 小断層サイズ, および破壞伝播速度の摇らぎの組み合わせで2011年東 北地震の時観測された2-10秒の長周期地震動が，5つの強震動生成域からの足し合わせでほ ぼ再現できることがわかった.

キーワード：2011東北地方太平洋沖地震，長周期地震動，強震動生成域

\section{1. はじめに}

2011年東北地方太平洋沖地震（以下，2011年東北地震とよぶ）では, 津波, 地殼変動, 遠地実体波, 強震動など，様々な観測データから，それぞれの観測データを再現する震源モデルのみでなく，異なる 
観測データを結合して同時に複数の観測データを満足する震源モデルが検討されている．近地の強震動 記録の長周期成分，遠地実体波の長周期成分，GPSによる測地データなど，長周期・超長周期地震動， および津波データの個別のデータを用いたインバージョン解析結果では, 寸べりの大きな場所が震源( 破 壊開始点）から海溝軸にかけた領域にあることが推定されている イント・インバージョンからは，大寸べり域はやや内陸よりの破壊開始点から海溝軸近くに至る領域に 推定されており ${ }^{6-7)}$, 若干の違いがみられる. その後, 久保ら ${ }^{8)}$ では, 近地強震記録を用いて, 5-10秒, 10-25 秒，25-50秒，50-100秒における周期別の震源モデルを構築し，震源過程には周期依存性があることをよ り明確に指摘している.

筆者らは，近地強震動記録の顕著な波群の解析から，強震動生成域（Strong Motion Generation Area， SMGA）を推定し，SMGAが陸側に近い場所に5つ存在することを明らかにした9)。これらの波群の地震 動は， 10 秒以下の短周期地震動成分が卓越する．この地震の短周期強震動は，震源断層面上に複数の強 震動生成域（SMGAs）を適切に配置し，経験的グリーン関数法を用いて再現できることが，複数の著者 により示されている9-13).

以上の研究から，2011年東北地震では，断層面上のすべりの場所毎に, 強く生成される強震動の卓越 特性が異なることが明らかになってきた. 近い将来, 発生の予測される南海トラフ地震など海溝型巨大 地震に対して超高層ビルなどの長周期構造物の被害予測およびその軽減策を検討するには，長周期地震 動（2-10秒）を事前に評価しておく必要がある。本研究では，長周期地震動（2-10秒）のための震源モ デルと評価手法の構築のために, SMGAからの波群の地震動の解析を行い, それらの震源スペクトルお よび震源から観測点までの伝播経路特性について議論する.

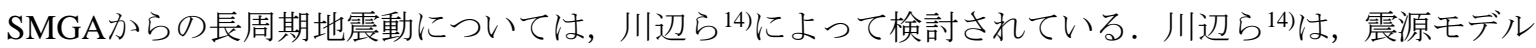
として経験的グリーン関数法により推定された複数のSMGAを用い, 伝播経路特性として3次元速度構造 を利用して実施した数值的シミュレーションにより, 2011年東北地震による4-10秒の長周期地震動が再 現できることを示した．有効な周期範囲が4秒以上とされているのは，3次元速度構造の推定精度の限界 のためと考えられる. 通常, SMGAは2秒以下の短周期地震動を生成する震源モデルとして活用されるが, この地震のSMGAは，2秒以下の短周期のみならず，工学的に重要な2秒以上から 10 秒に至る比較的広帯 域の長周期地震動を生成していることを示唆している。しかしながら，彼らのシミュレーションで用い られたすべり時間関数や速度構造を仮定した数值的評価方法が, 経験的グリーン関数による評価方法と 等価かどうかは必ずしも明確に示されていない。

震源域の近傍で発生した小地震の記録を経験的グリーン関数として用いてSMGAから放出される地震 動を求め, 大地震の地震動を合成できることはすでに知られている. Irikura ${ }^{15}$ による経験的グリーン関 数法は, 経験的グリーン関数として用いる小地震の波形記録の震源スペクトルが $\omega^{-2}$ 則に従っているこ とに基づき，小地震記録の重ねあわせで合成された大地震の震源スペクトルが $\omega^{-2}$ 則に従うよう工夫さ れている.したがって, 2011年東北地震のSMGAからの地震動のスペクトルは短周期域において $\omega^{-2} て ゙$ 近 似できることが示唆されるが， $\omega^{-2}$ 則が有効な周期範囲は定量的には示されていない.

本研究では, まず, 2011年東北地震のSMGAから放出された地震動の観測記録を用いて, それらのス ペクトル特性を確認する. SMGAからの地震動が 2 秒以下の短周期域のみならず，2秒から 10 秒の工学的 に重要な長周期帯域でも $\omega^{-2}$ 則に従っている前提条件を確認した後に，すべり時間関数と理論的グリー ン関数を用いて数值的シミュレーションにより， $\omega^{-2}$ 則に従う地震動を合成する方法を検討する.

一般に, SMGAから放出される地震動の合成は，1）SMGAを小断層に分割し，2）各小断層を点震 源とみなして震源時間関数を設定し, 3 ) 震源と観測点間の速度構造を考慮してグリーン関数を計算し, 4) 震源時間関数とグリーン関数の重畳により計算される小断層からの地震動を重㸚わせる，手順で 行われる.各小断層で設定される震源時間関数は, 震源断層面上の寸べり時間関数に相当することから, 以後すべり時間関数と呼ぶ. 合成された地震動は, SMGAのサイズ効果とすべり時間関数のスペクトル

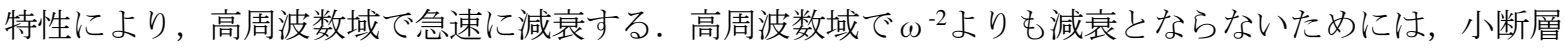
のサイズとすべり時間関数の適切な組み合わせを選定する必要がある.

本研究で対象としている2-10秒の長周期地震動を評価するには, 震源特性のみならず震源から観測点 までの3次元速度構造による伝播経路特性の適切な評価が必要であるが, 両方の特性を同時に精度よく検 証することは一般的に困難である。ここでは，伝播経路特性に関しては，震源域周辺に発生した小地震 
の観測記録から1次元速度構造を同定して得られた理論的グリーン関数を用いる.

本研究の最終目標は, 2011年東北地震のような海溝型超巨大地震から工学的に重要な2秒から10秒の長 周期地震動を理論的にシミュレーションする手法を検証することにある.

\section{2011 年東北地方太平洋沖地震のSMGA震源モデル}

本研究で用いるSMGA震源モデルは，Kurahashi and Irikura9)が，震源域近くで発生した小地震記録を経 験的グリーン関数として，対象周波数 $0.15 \sim 10 \mathrm{~Hz}$ の最適化モデルとして求めたものである.

本震の観測記録は，KiK-net・K-NET強震動観測網（以下，KiK-net・K-NETとよぶ）などで観測され ており, 強震動はいくつかの波群により形成されていることが知られている. 図1にはKiK-net とK-NET の観測点分布と 2011 年東北地震の震源域に沿った観測点で記録された観測波形のペーストアップを示す. この図より，宮城県付近の観測記録には明瞭に2つの波群（WP1とWP3）が含まれていることがわかる. 一方で，茨城県付近の観測記録は，約150秒付近から別の大きな波群（WP5）が見えている. 宮城県と 茨城県の中間に位置する福島県の観測記録は, いくつもの波群が重なるようにかなり複雑な波形をして いる. Kurahashi and Irikura9)では，少なくとも5つの波群がみられることを示し，また，これらの波群が 個別のSMGAから生成されたとして, 5つのSMGAの位置, 面積, 応力パラメータを推定している. なお, 本論文では, 各SMGAの名称を, 図1の波群名と一致させて表す（図1の波群1（WP1）はSMGA1から, 波群2（WP2）はSMGA2から放出された地震動を示している）。

SMGAの位置は, KiK-net・K-NETにおいて震源近傍域で得られた強震動記録に顕著にみられるいくつ かの波群を用いて2種類の解析手法で推定されている.1つは，強震観測点を複数の小アレイに分類し， その小アレイごとに観測された波群を対象にセンブランス解析から波群の伝播方向を推定し，それぞれ

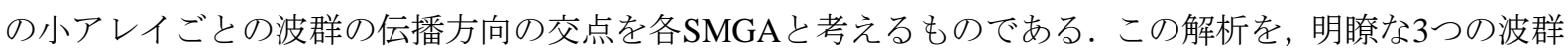

（WP1，WP3，WP5）について実施されている. その結果, 宮城県の強震動観測点で明瞭に記録されて いる2つの波群（WP1とWP3）については，WP1に対応するSMGA1は，破壊開始点と陸との中間の位置 に推定にされ，WP3に対応するSMGA3は，SMGA1 と破壊開始点との間に位置すると推定されている. もう1つは, それぞれの波群の立ち上がり時間を読み取り, 強震動の放射点に向けて逆伝播させる方法で 波群の発生域の特定を行っており，WP2およびWP4に対して実施されている.

各SMGAの面積と応力パラメータについては, 個々のSMGAの近傍で発生した中小地震の観測記録を 経験的グリーン関数として, 波形合成法 ${ }^{15)}$ により計算される波形とのフィッティングから推定された. 結果的に, 本地震の5つのSMGAの応力パラメータは, 16 26MPaの範囲に求められた. 図2 に本地震の SMGA震源モデルを示す，推定された5つのSMGAは，破壊開始点の西の陸側寄りの，震源断層の西端に 近いダウンディップに沿う位置に推定されている．表1と表2には，経験的グリーン関数として用いた小 地震の震源の諸元と, 推定したSMGA震源モデルの諸元を示す. また, 図3には, 宮城県のKiK-net観測 点（MYGH12（志津川）, MYGH06（田尻）, MYGH08（岩沼））および女川原子力発電所（ONG128） の観測波形と経験的グリーン関数法で計算された計算波形のNS成分の加速度, 速度, 変位の比較の一例 を示寸. 観測波形で見られる明瞭な波群および振幅がほぼ再現できていることが確認できる. また，図4 には久保ら息による周期別の震源モデルとSMGA震源モデルを重ね合わせた図を示す. 長周期地震動を強 く放出する震源モデルは海溝軸周辺の大きなすべりに対応しており, 短い周期の地震動を放出した震源 は陸域に位置するように見える。この周期別のすべり分布は, 短周期地震動を生成するSMGAが震源断 層の西端域のダウンディップに位置することと定性的に対応している.

Kurahashi and Irikura')では, さらに, 本震の破壊開始点に近い女川原子力発電所や宮城県のKiK-net ・ K-NET観測点で観測された波群の先頭部にみられる衝撃波形の再現について検討されている（図3の MYGH12やONG128観測点の速度波形の100秒付近）。Kurahashi and Irikura9 ${ }^{9}$ は，この衝撃波形の再現と して, SMGA内にさらに不均質な領域があると考え, SMGA内の1小断層分の応力パラメータを 2 4倍す ることで再現できることを示した．この波群の先頭部に見られる衝撃波形は，加速度波形で顕著にみら れが, このパルスは約 0.5 秒で, 本研究で対象としている2 10秒よりも短周期であるため, 本研究ではこ のパルス波形およびSMGAの不均質性についての検討を除外した．なお，本研究では，対象としている 周期範囲より，速度波形と変位波形を対象としている。 
(a)

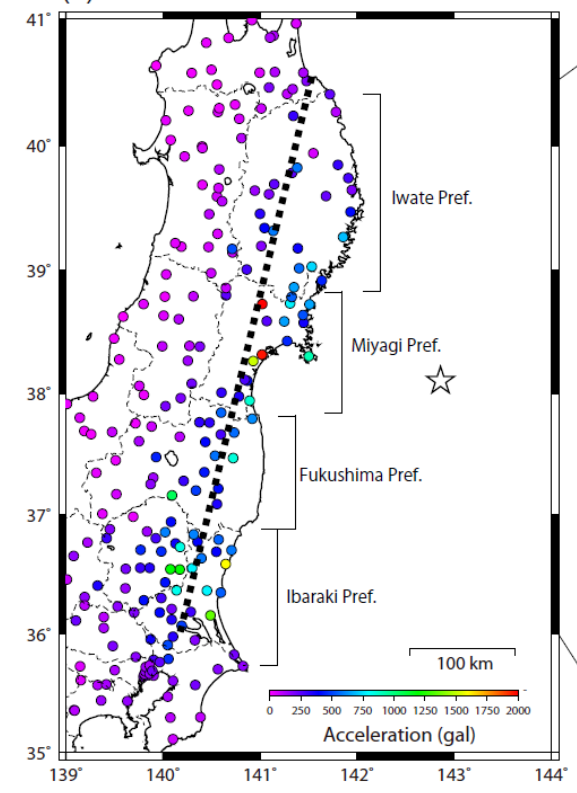

(b) 2011/3/11 14:46 NS Acceleration

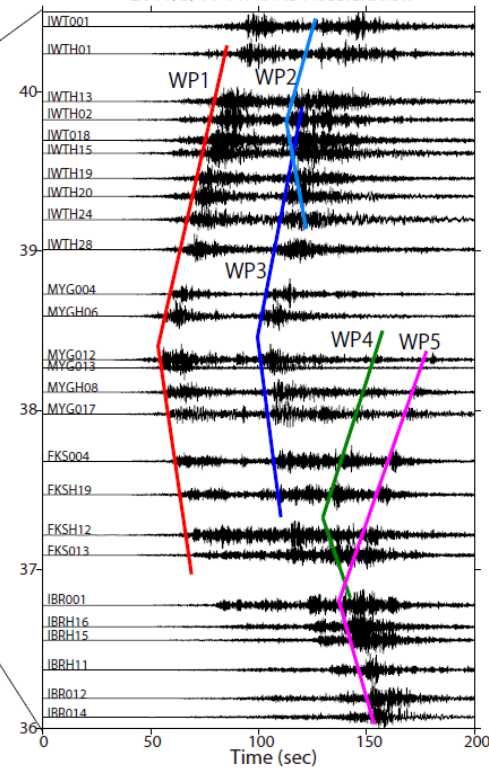

図1（a）2011年東北地震の記録が観測されたK-NETおよびKiK-netの観測点分布. 観測点の色は最大加速 度値を示し, 点線は2011年東北地震の震源域と概ね平行した線を示す. 星印は本震の破壊開始点を示す. (b) 本震の加速度観測波形.（a）に示した点線上に位置する観測点の観測波形を北から順に示している. 波群が到着した順にWP1からWP5と示している.

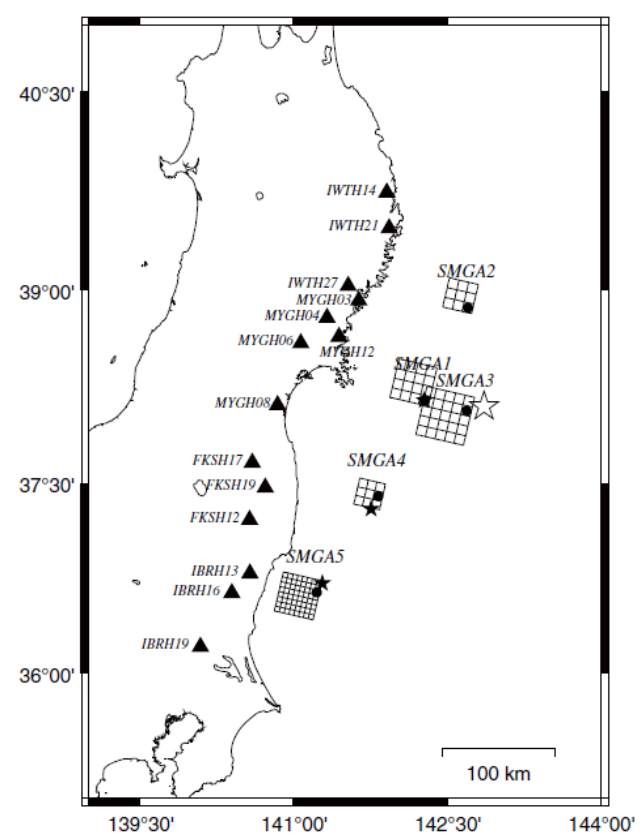

図2 Kurahashi and Irikura9)によるSMGA震源モデル. 白抜き星, 黒星, 黒丸はそれぞれ，本震，経験的 グリーン関数法に使用した地震およびSMGAの破壊開始点を示す．矩形は，SMGAの位置と大きさおよび小 断層の数を示す. 
表1 Kurahashi and Irikura ${ }^{9)}$ で使用された経験的グリーン関数の諸元

\begin{tabular}{|c|c|c|c|}
\hline & Origin time & $\begin{array}{c}\text { M0 } \\
(\mathrm{Nm})\end{array}$ & $\begin{array}{c}\text { Stress } \\
\text { Parameter } \\
(\mathrm{MPa})\end{array}$ \\
\hline \hline EGF A & $2005 / 8 / 1611: 46$ & $5.23 \times 10^{18}$ & 20.0 \\
\hline EGF B & $2007 / 11 / 2622: 51$ & $7.66 \times 10^{17}$ & 4.2 \\
\hline EGF C & $2009 / 2 / 106: 52$ & $4.65 \times 10^{17}$ & 10.4 \\
\hline
\end{tabular}

表2 Kurahashi and Irikura ${ }^{9)}$ のSMGA震源モデルの諸元.

EGF欄は，経験的グリーン関数として用いた地震（表 1 で示された地震に対応）を示す.

\begin{tabular}{|c|c|c|c|c|}
\hline & EGF & $\begin{array}{c}\mathrm{L} \times \mathrm{W} \\
(\mathrm{km})\end{array}$ & $\begin{array}{c}\text { M0 } \\
(\mathrm{Nm})\end{array}$ & $\begin{array}{c}\text { Stress } \\
\text { Parameter } \\
(\mathrm{MPa})\end{array}$ \\
\hline \hline SMGA1 & EGF A & $34.0 \times 34.0$ & $2.68 \times 10^{20}$ & 16.0 \\
\hline SMGA2 & EGF A & $25.5 \times 25.5$ & $1.41 \times 10^{20}$ & 20.0 \\
\hline SMGA3 & EGF A & $42.5 \times 42.5$ & $6.54 \times 10^{20}$ & 20.0 \\
\hline SMGA4 & EGF B & $23.1 \times 23.1$ & $1.24 \times 10^{20}$ & 25.2 \\
\hline SMGA5 & EGF C & $35.2 \times 35.2$ & $5.95 \times 10^{20}$ & 26.0 \\
\hline
\end{tabular}
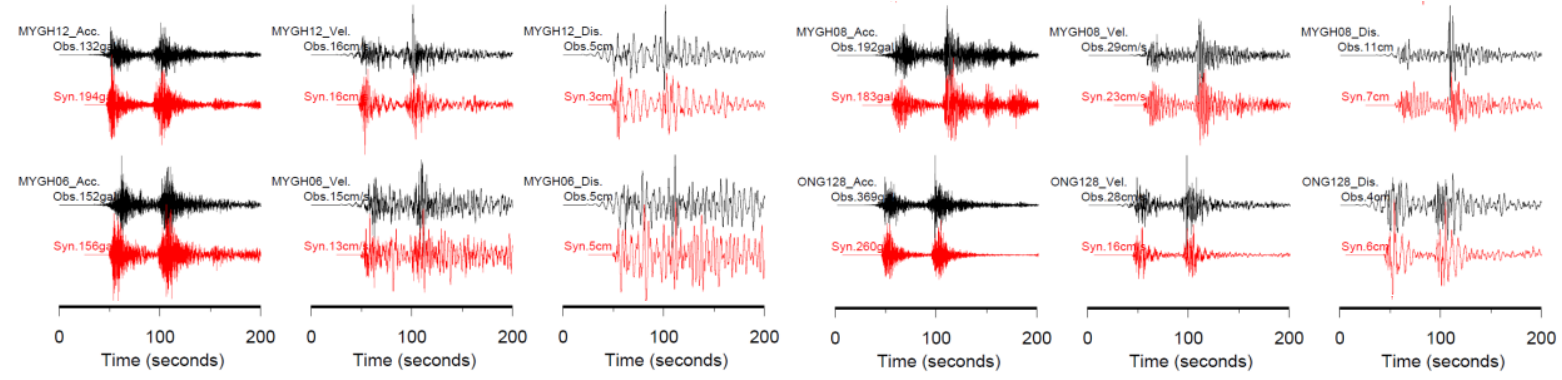

図3 宮城県の地震観測点（MYGH12（志津川），MYGH06（田尻），MYGH08（岩沼），ONG128（女川原発-128m 地点））における観測波形（黒）とKurahashi and Irikura ${ }^{9}$ で計算された合成波形（赤）の比較. 各記 録ともNS成分を示し, 左から加速度, 速度, 変位波形を示す。

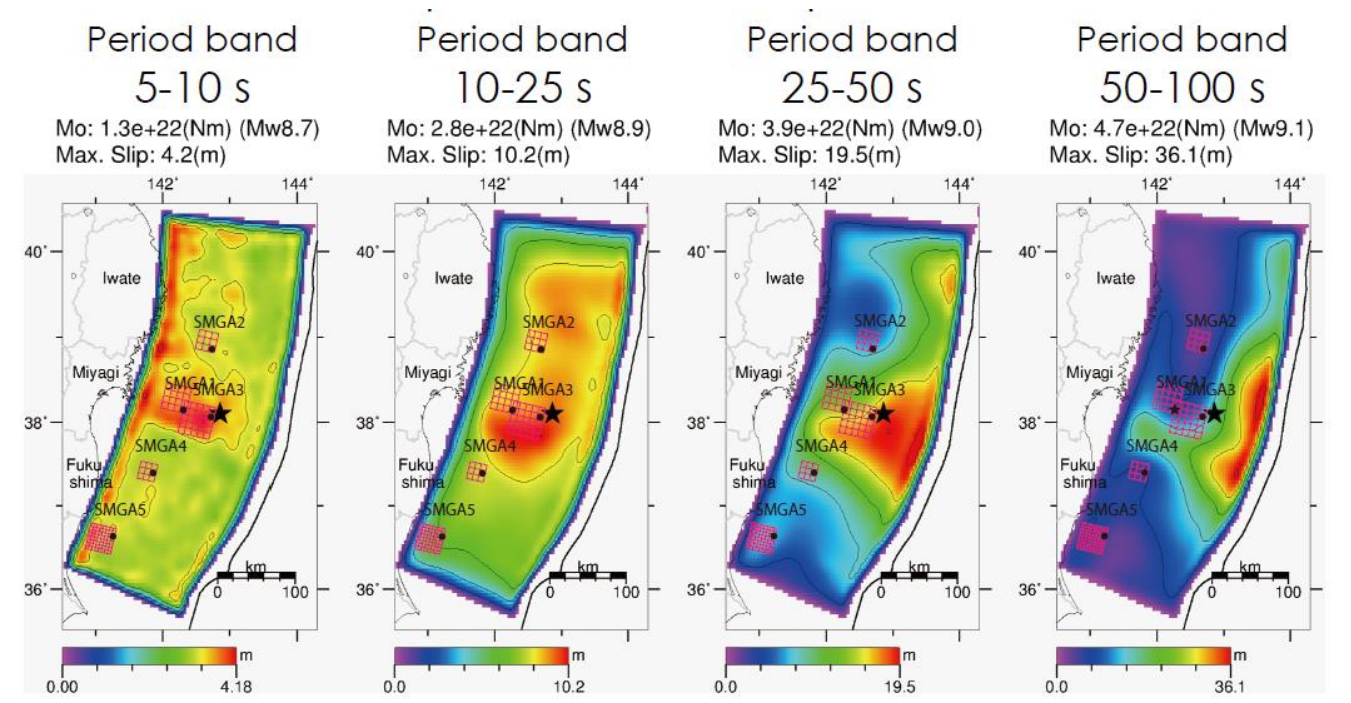

図4 SMGA震源モデル（赤色の矩形） と近地長周期地震動のすべり分布（久保ら ${ }^{8)}$ ) との比較

\section{SMGAからの地震動の周期特性}

SMGAから生成される地震動は, これまで，内陸の地震に関しては一般にほぼ $\omega^{-2}$ 則に従うとして強震 
動の合成がなされ，観測に良く一致する波形が得られた（例えば，Irikura and Miyake ${ }^{16)}$; 池田ら ${ }^{17)}$ ) 。海 溝型地震に関しては，必ずしも一般的な結論は得られていないが，2003年十勝沖地震（Mw8.3）や2005 年宮城県沖地震（Mw7.2）では，経験的グリーン関数法により観測地震動が再現される論文がだされて おり，結果的にSMGAからの地震動は $\omega^{-2}$ 則に沿っていたことが示唆される18-19)。一方で，1978年宮城県 沖地震(Mw 7.6)や2003年十勝沖地震(Mw 8.3)では, SMGAから放射された地震動は $\omega^{-2}$ 則には従わず， 2 つのコーナー周波数をもつモデルであったことが報告されている20).

M9の超巨大地震である2011年東北地震のSMGAからの地震動がどのような周期特性をもつかについ ては, 次節(3.1)で検討する. そして, 次々節 (3.2) では, SMGAからの地震動を合成するために, SMGA を小断層に分割し，各小断層を点震源と見なして，すべり時間関数と理論的グリーン関数で計算される 地震動の重㸚わせにより波形合成する方法について検討する.

\section{1 SMGAからの地震動および全破壊域からの地震動の周期特性}

2011年東北地震の震源近傍域で得られた観測記録をみると, 孤立した波群として, 3つの波群（WP1, WP3，WP5）が認められる（図1参照）。これらの波群は，SMGA1，SMGA3，SMGA5からの地震動と 考えることができる9).ここでは，これらの3つの波群の記録から，震源スペクトルを推定する．解析に は，地盤による地震波増幅や散乱の影響が少ないと考えられる，地盤のS波速度が $2000 \mathrm{~m} / \mathrm{s}$ 以上の地点に 設置されているKiK-netの地中観測点での観測記録を用いた.

各波群の解析対象とする時間空については，観測波形のペーストアップから，各波群の始まり部分を 目視で読み取り, その5秒前から40.96秒間のデータ長を切り出した. 切り出した40.96秒の前後に0を加え て，データ長を327.68秒に拡大してフーリエスペクトルの計算を行ったが，計算されたスペクトルのう ち0.024Hz以下の周波数 (40.96秒より長周期)のスペクトルついては精度がない.

観測記録のスペクトルを伝播経路特性である幾何学的減衰 $(1 / \mathrm{R})$ と媒質による減衰 $[\exp (-\pi \mathrm{fR} / \mathrm{VsQ})]$

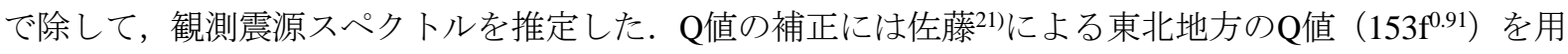
いた。このようにして計算された各波群の観測震源スペクトルを図5に示す。また，図5には，SMGAか

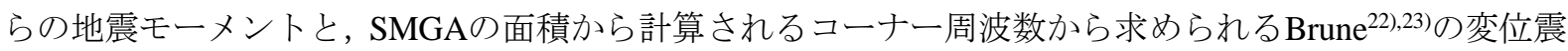
源スペクトルを赤線で示す。ここでの観測震源スペクトルは，地表面効果を含む表層効果で増幅された ものとなっている. そのため, 観測震源スペクトルは, SMGAの地震モーメントと面積から計算される Bruneのスペクトルに比べて，2倍程度大きくなっている.

KiK-netの観測記録に含まれる地中地盤特性は, 赤澤・入倉24)で詳細に検討されている. それによると， 硬質地盤における地中地盤特性は, $1 \mathrm{~Hz}$ 以下の低周波数域では, 自由地表面の効果 $(=2)$ にほぼ漸近す ることが示されている. そこで, 地中地盤特性を考慮して, 低周波数側を地震モーメントの 2 倍とし，コ 一ナー周波数より高周波数側が $\omega^{-2}$ で減衰するとした模式スペクトルを青線で図 5 に示す. 結果として, 各SMGAに対応する波群（WP1, WP3, WP5）の観測震源スペクトルは, KiK-netの観測記録に含まれる地 中地盤効果を考慮すると, 概ね $\omega^{-2}$ 則で近似できることがわかった.

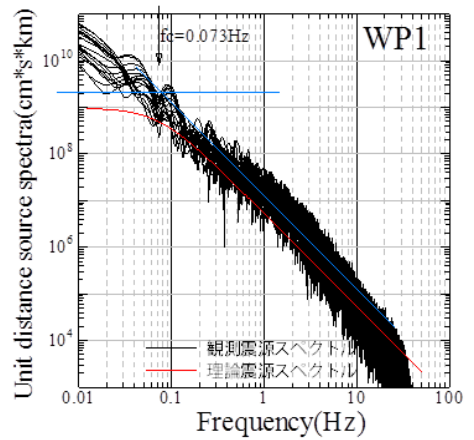

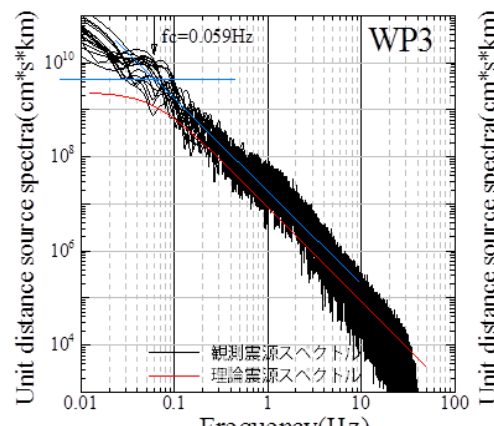

Frequency $(\mathrm{Hz})$

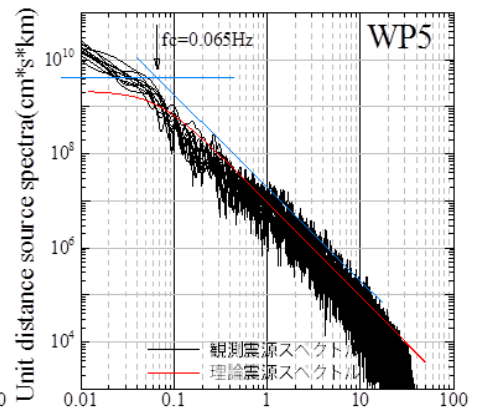

Frequency $(\mathrm{Hz})$

図5 観測波形からみられた波群1（WP1），波群3（WP3），波群5（WP5）における地中記録から推定した 観測震源スペクトル（黒）とBrune ${ }^{22), 23)}$ の変位震源スペクトル（赤）。青線は, 地盤増幅度を考慮した 場合のBrune $\left.{ }^{22)}, 23\right)$ の変位震源スペクトルを示す. 


\section{2 SMGAからの地震動評価のためのすべり速度時間関数と小断層サイズの選定}

各SMGAからの観測記録のスペクトルは，図5に示されるように，コーナー周波数より低周波数域でフ ラットな特性を有し, 高周波数域で $\omega^{-2}$ に減衰寸る，いわゆる $\omega^{-2}$ 則の特性を示していることが確認され た.したがって, SMGAからの地震動のシミュレーションは, 分割する小断層のサイズとすべり速度関 数を適切に決め，重社合わせで得られる合成波形が高周波数域において $\omega^{-2}$ で減衰するスペクトルをも つようにしなければならない。ここでは，小断層サイズを変えた6ケース $(0.25 ， 0.5 ， 1.0 ， 2.1 ， 4.2 ， 8.5$ $\mathrm{km}$ ）を検討する．なお，表3に，小断層サイズを変えた6ケースにおける足し合わせ数を示す.

すべり速度関数には, boxcar関数，三角形関数， smoothed ramp 関数，中村-宮武 ${ }^{25}$ の関数（以下，中 村・宮武の関数とよぶ）などがよく利用される。ここでは，smoothed ramp 関数と中村・宮武の関数の 利用について検討寸る. smoothed ramp 関数と中村・宮武の関数の時刻歴波形を図6左に，それらのフー リエスペクトルを図6右に示す. smoothed ramp関数は最終すべり量とライズタイム $\left(\mathrm{t}_{\mathrm{r}}\right)$ で与えられる. そ のす心゙り継続時間はライズタイムに等しい。一方，中村・宮武の関数は，最終す心゙り量，最大すべり速 度到達時間（ $\mathrm{f}_{\text {max }}$ に対応），ライズタイムの3つのパラメータで与えられる. すべり継続時間 $\left(\mathrm{t}_{\mathrm{s}}\right)$ は, $\mathrm{t}_{\mathrm{r}}+\mathrm{t}_{\mathrm{r}} / 2$ となる. 図6では，すべり速度関数を特徴づけるパラメータであるライズタイムおよび $\mathrm{f}_{\max }$ はそれぞれ， 3.7秒, $6.0 \mathrm{~Hz}$ している. smoothed ramp関数のフーリエスペクトルは, 低周波数域からライズタイムの 逆数の周波数 $(0.27 \mathrm{~Hz})$ までほぼフラットで，ライズタイムの逆数から高周波数域で急激に減衰する. 一方で，中村・宮武の関数は，すべり継続時間の逆数に対応する周波数までフラットで，それより高周 波数で $\omega^{-1 / 2}$ でゆっくり減衰する.

ここで, SMGA3（S=42.5×42.5 km）を対象とした, 理論波形の変位フーリエスペクトルを計算する. はじめに，すべり速度関数をデルタ関数とし，小断層サイズを $0.25 ， 0.5 ， 1.0,2.1 ， 4.2,8.5 \mathrm{~km}$ とて 波形合成した結果の変位フーリエスペクトルを図7に示寸. 図中の灰色線は, 地震モーメントをKurahashi and Irikura ${ }^{9}$ によるSMGA3の值，コーナー周波数をSMGA3の面積と媒質S波速度から推定される $0.059 \mathrm{~Hz}$ とした場合のBrune ${ }^{22), 23)}$ による変位震源スペクトルを示している. 図より, 小断層サイズが $8.5 \mathrm{~km}$ 場合

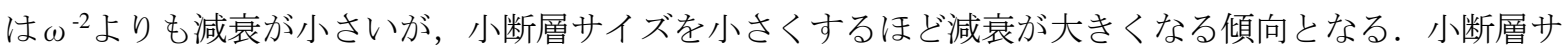
イズ $1 \mathrm{~km}$ の場合で，ほぼ $\omega^{-2}$ と同じ減衰傾向を示す。これは，小断層サイズを小さくすると，各小断層の 足し合わせ（すなわち解析的な積分）が連続的にされることに対応しているためである。また， $\omega^{-2} に$ 近づく傾向は，有限長の効果が表れていることを示し，計算が理論通りなされていることがわかる．小 断層サイズが解析対象の波長に比べて十分小さくない時は，コーナー周波数よりも高周波でランダムな 足し合わせ効果が発生し，高周波の落ち込みが $\omega^{-2}$ より 小さくなる.

実際の断層面からの地震動を考えた場合, すべり速度関数としては, デルタ関数ではなく, smoothed ramp関数や中村・宮武の関数で，それら自体が高周波で減衰する特徵を持つ。したがって，これらのす

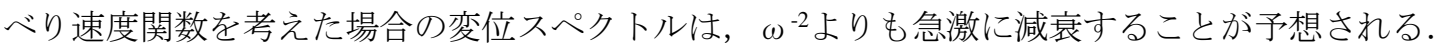

そこで，すべり速度時間関数として smoothed ramp関数および中村·宮武の関数のそれぞれを用いて， 小断層サイズを $0.25 ， 0.5 ， 1.0 ， 2.1 ， 4.2 ， 8.5 \mathrm{~km}$ とて波形合成した結果について，変位フーリエスペ クトルを計算したものを図8に示す。ここでライズタイムは，Kurahashi and Irikura' デルのSMGA3の值である3.7秒とし，図6で示されるすべり速度関数と同じ值としている．また，破壊伝 播速度はKurahashi and Irikura ${ }^{9}$ に従い $2.8 \mathrm{~km} / \mathrm{s}$ している. 図8左図にsmoothed ramp関数を用いた場合の SMGA3からの地震動の変位スペクトルを示寸. 図中の灰色線は, 地震モーメントをKurahashi and Irikura9) によるSMGA3の值, コーナー周波数をSMGA3の面積と媒質S波速度から推定される $0.059 \mathrm{~Hz}$ とた場合 のBrune ${ }^{22), 23}$ による変位震源スペクトルを示している. 図より, 合成波形の変位フーリエスペクトルの振

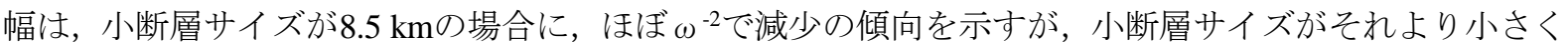

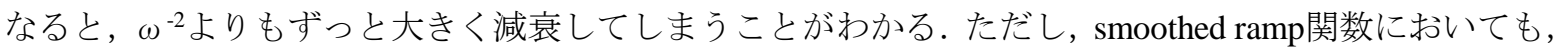

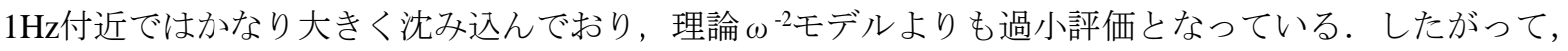
本論の方法においても, 高周波数側の限界周波数は $0.5 \mathrm{~Hz}$ 程度である.

中村・宮武の関数を用いた場合の合成波形の変位フーリエスペクトルを図8右図に示寸.この関数を用

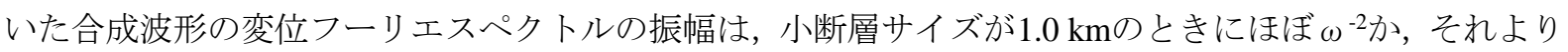
も若干大きく減少している. 小断層サイズがそれより大きいと高周波側のスペクトルの振幅の減衰は $\omega$

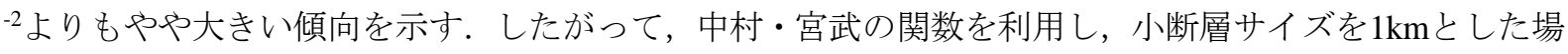


合， $\omega^{-2}$ の減衰にするために，一般的には破壊伝播速度の摇らぎを与える方法が利用されている．そこ で，次に破壊伝播速度の摇らぎの影響を確認する．なお， smoothed ramp関数および中村・宮武の関数の 場合でも $1.0 \mathrm{~km} よ り$ 小くしても，高周波数域での減少傾向はほとんど変わらなくなる．なお，図7に関 して, 小断層サイズが小さくなるにつれて $0.2 \sim 0.5 \mathrm{~Hz}$ 付近の振幅が小さくなる.これは, Irikura and Kamae (26)で指摘されている，一定の時間間隔の足し合わせを行った時，コーナー周波数より高周波数側の中間 周波数で足し合わせ数の増加による振幅の落ち込みの効果が原因と考えられる。これの減衰には，破壊 伝播速度の摇らぎと小断層のサイズに摇らぎを与えるなど，別途検証が必要である.

次に，破壊伝播速度に摇らぎを与えた場合における，合成波形の変位フーリエスペクトルの振幅特性 の検討を行った。上記までは，SMGAを分割した各小断層の破壊開始時間は，破壊開始点から断層面上 を一定の速度で，円状に破壊が進行したことを仮定して計算した．しかしながら，SMGAの小断層毎の 破壊伝播速度には摇らぎがある可能性も考えられる。この時，各小断層からの地震動の観測点への到達 時刻がよりランダムになるため，高周波成分については，インコヒーレント性が強まり，スペクトルの 高周波数側での減衰傾向は小さくなると推測される。ここでは, 上記の計算に利用した破壊伝播速度を 平均 $2.8 \mathrm{~km} / \mathrm{s}$ として, これに $10 \%$ おび゙士 $20 \%$ の摇らぎを与えた場合の, 合成波形のスペクトル形状の 確認を行った（図9）。本研究では，摇らぎを与える乱数を一様乱数とした．また，摇らぎの空間的相関 などは考慮せず，生成した乱数を単純に破壊伝播速度の摇らぎとして与えた．なお，各小断層の破壊開 始時間は，Hisada ${ }^{(27)}$ の方法を用いた。この方法は，因果律を満たさない方法であるが，因果律を満たす 方法との結果に大きな違いが見られないことを確認している.

摇らぎを与えていない小断層サイズ $1.0 \mathrm{~km}$ で計算した計算波形の変位フーリエスペクトルとの比較か ら，破壊伝播速度に摇らぎを与えると，高周波側で減衰傾向が小さくなることを確認した．また，摇ら ぎを $10 \%$ から $20 \%$ と大きく寸ることで咸衰がより小さくなることが確認できた．このように，高周波が 減少しすぎることをさけるために, 破壊伝播速度に摇らぎを与えることが効果的であることを確認した。
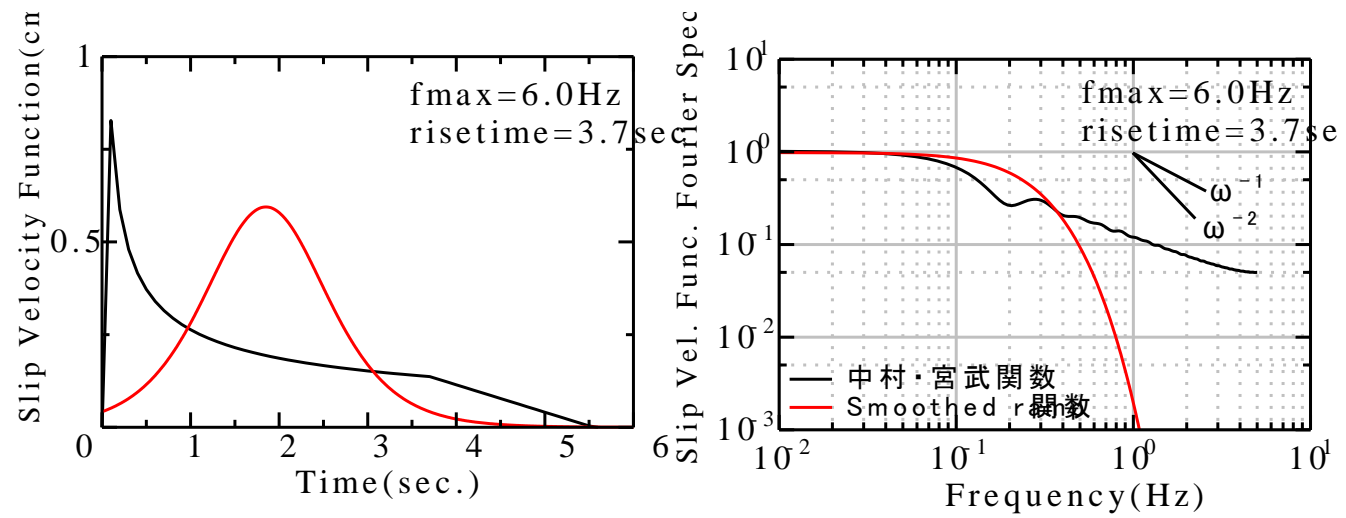

図6 中村·宮武の関数（黒）およびSmoothed ramp関数（赤）の時刻歴波形（左図）と フーリエスペクトル（右図）。

表3 小断層サイズと足し合わせ数

\begin{tabular}{|c|c|c|c|}
\hline メッシュサイズ & $\mathrm{NL}$ & $\mathrm{NW}$ & 足し合わせ数 \\
\hline \hline $0.25 \mathrm{~km}$ & 170 & 170 & 28900 \\
\hline $0.5 \mathrm{~km}$ & 85 & 85 & 7225 \\
\hline $1.0 \mathrm{~km}$ & 42 & 42 & 1764 \\
\hline $2.1 \mathrm{~km}$ & 20 & 20 & 400 \\
\hline $4.2 \mathrm{~km}$ & 10 & 10 & 100 \\
\hline $8.5 \mathrm{~km}$ & 5 & 5 & 25 \\
\hline
\end{tabular}




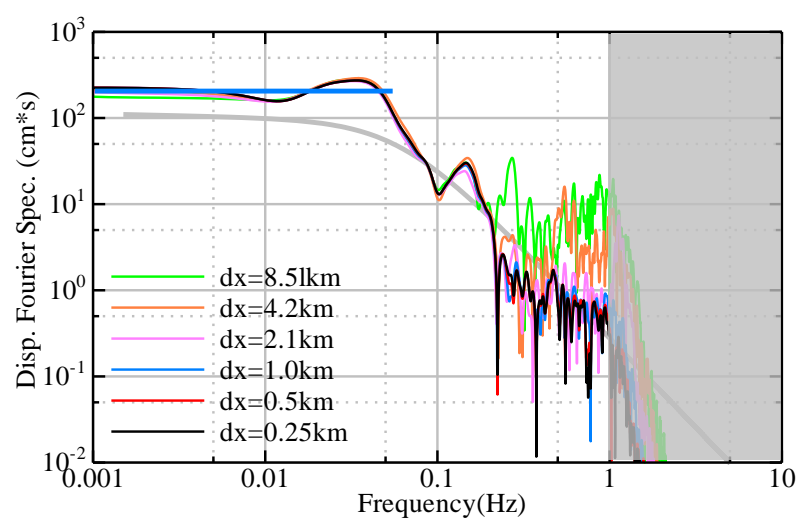

図7 MYGH04観測点における小断層サイズを変えた場合の変位フーリエスペクトル. すべり速度関数とし てデルタ関数を利用した場合の結果を示す. 灰色線は, Kurahashi and Irikura ${ }^{9}$ におけるSMGA3の地震 モーメントとコーナー周波数から与えられるBrune ${ }^{22), 23)}$ の変位震源スペクトルを示す. 青線は, 地盤増 幅度を考慮した場合のBrune ${ }^{22)}$, 23) の変位震源スペクトルを示す.
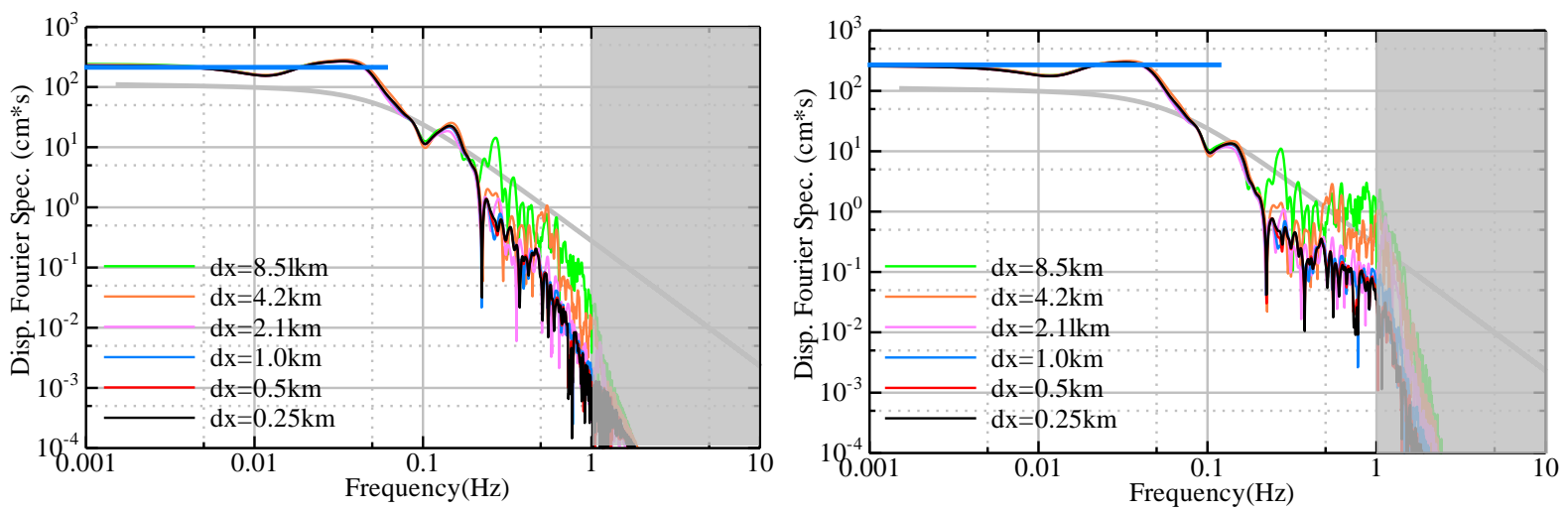

図8 MYGH04観測点における小断層サイズを変えた場合の変位フーリエスペクトル（右図）すべり速度 関数としてsmoothed ramp関数を利用した場合，（左図）すべり速度関数として中村・宮武の関数を利用 した場合の結果を示す. 灰色線は, Kurahashi and Irikura9)におけるSMGA3の地震モーメントとコーナ 一周波数から与えられるBrune ${ }^{22)}{ }^{23}$ の変位震源スペクトルを示す．青線は，地盤増幅度を考慮した場合 のBrune ${ }^{22), 23)}$ の変位震源スペクトルを示す.

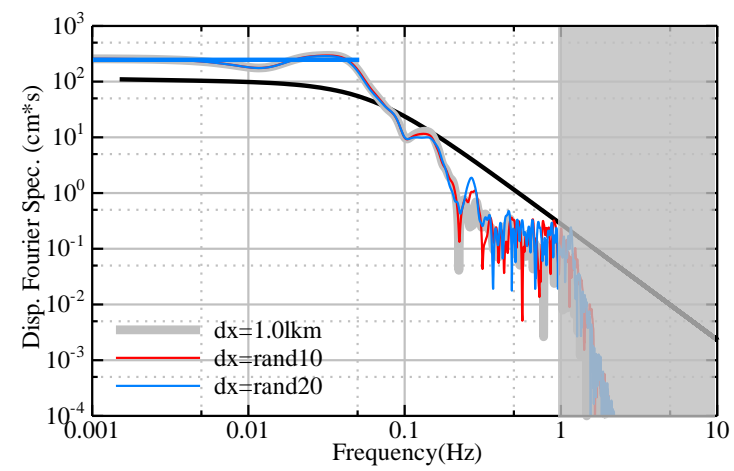

図9MYGH04観測点における破壊伝播速度にばらつきを与えた場合の変位フーリエスペクトル.すべり速 度関数として中村・宮武の関数を利用し，小断層サイズは1. $0 \mathrm{~km}$ 利用した結果を示す．黒色線は, Kurahashi and Irikura9) におけるSMGA3の地震モーメントとコーナー周波数から与えられるBrune ${ }^{22), 23)}$ 変位震源スペクトルを示す．青線は，地盤増幅度を考慮した場合のBrune ${ }^{22), 23)}$ の変位震源スペクトルを 示す. 


\section{4. 長周期地震動シミュレーション}

SMGA震源モデルを用いて長周期地震動シミュレーションを実施した。 長周期地震動のシミュレーシ ヨンには, 離散化波数法 ${ }^{28)}$ と反射透過係数法 ${ }^{29}$ を使用した. また, 寸べり速度関数には, smoothed ramp 関 数と中村・宮武の関数を用いて計算を実施した.

地震動評価の対象地点は, 2011年東北地震の強震動を観測したKiK-net観測点の8観測点（MYGH04（東 和）, MYGH08（岩沼）, FKSH12（平田）, FKSH19（都路）, IBRH12（犬子）, IBRH19（つくば）, CHBH13（成田），TKYH12（八王子））とした。各観測点の地盤構造モデルは，小地震の観測記録を 用いて物性值の同定を行った。

\section{1 速度構造モデルの推定}

速度構造モデルの推定に用いた小地震と対象地点およびその緒元を図 10 と表4に示す.初期地盤構造モ デルは，以下のものを利用した。

・ごく浅い部分の地盤構造モデル：KiK-netのボーリングデータ

・13km以浅の浅部地盤構造モデル : 藤原ら ${ }^{30)}$

・13km以深の深部地盤構造モデル : Wu et al. ${ }^{31)}$

地盤構造の同定には，焼きなまし法を利用し，速度波形を用いた。同定する最適モデルは，次式の評 価関数Em(misfit)が最小となるモデルとした。

$$
\operatorname{Em}(\text { misfit })=\sum_{\text {compnent }}\left\{\frac{\sum_{t}\left(u_{o b s}-u_{s y n}\right)^{2}}{\sqrt{\sum_{t} u_{o b s}{ }^{2} \times \sum_{t} u_{s y n}^{2}}}\right\}
$$

なお，地盤構造の同定は，浅部地盤は深さのみを同定パラメータとして解析を行い, $\mathrm{S}$ 波速度, $\mathrm{P}$ 波速度, 密度は，初期モデルから変動させていない。また，深部地盤はS波速度のみを同定パラメータとして解 析を行った．図11に全観測点の観測波形と同定地盤構造から計算した理論波形の比較を示寸．全観測点 にて，観測波形を満足していることが確認できる．図12に初期地盤構造モデルと地盤構造同定の比較結 果を示す.

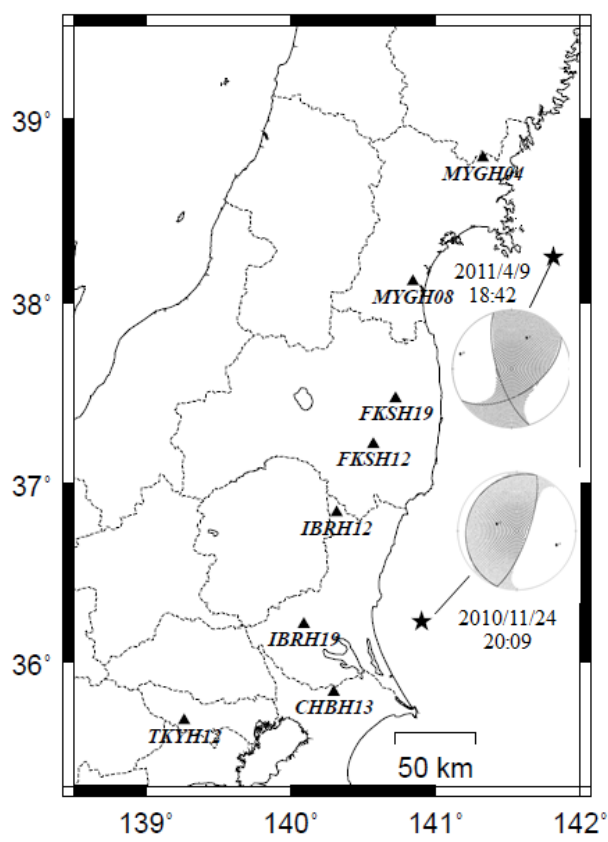

図10 速度構造モデルの同定に利用した地震の震央位置と震源球および解析に利用した観測点位置. 
なお，小地震の発生した場所と対象観測点との幾何学的な位置関係などにより，小地震により平行成 層構造を仮定して同定される地盤構造は少なからず変化すると考えられる。しかし，その変動が大きく なければ, 強震動シミュレーションへの影響も少ないと考えられる. 確認のため, 違う小地震により, 同定された地盤構造を基に理論地震動を計算し，観測波形と比較した結果，概敞観測波形が再現できた ことを確認した。

表4＼cjkstart速度構造モデルの同定に利用した地震の諸元

\begin{tabular}{|l|l|l|}
\hline 発生時間(JMA) & $2011 / 4 / 918: 42$ & $2010 / 11 / 2420: 09$ \\
\hline マグニチュード(F-net) & $M w 5.4$ & $M w 4.9$ \\
\hline 震源位置(JMA) & $38.247,141.815,58.2 \mathrm{~km}$ & $36.229,140.902,47.1 \mathrm{~km}$ \\
\hline 震源メカニズム(F-net) & (str:dip:rake= & (str:dip:rake= \\
\hline 地震モーメント(F-net) & $162 / 57: 71 / 53: 39 / 156)$ & $20 / 199: 74 / 16: 90 / 89)$ \\
\hline \multirow{2}{*}{ 対象観測点 } & MYGH04、MYGH12、 & $2.69 \mathrm{e}+16 \mathrm{Nm}$ \\
\hline
\end{tabular}

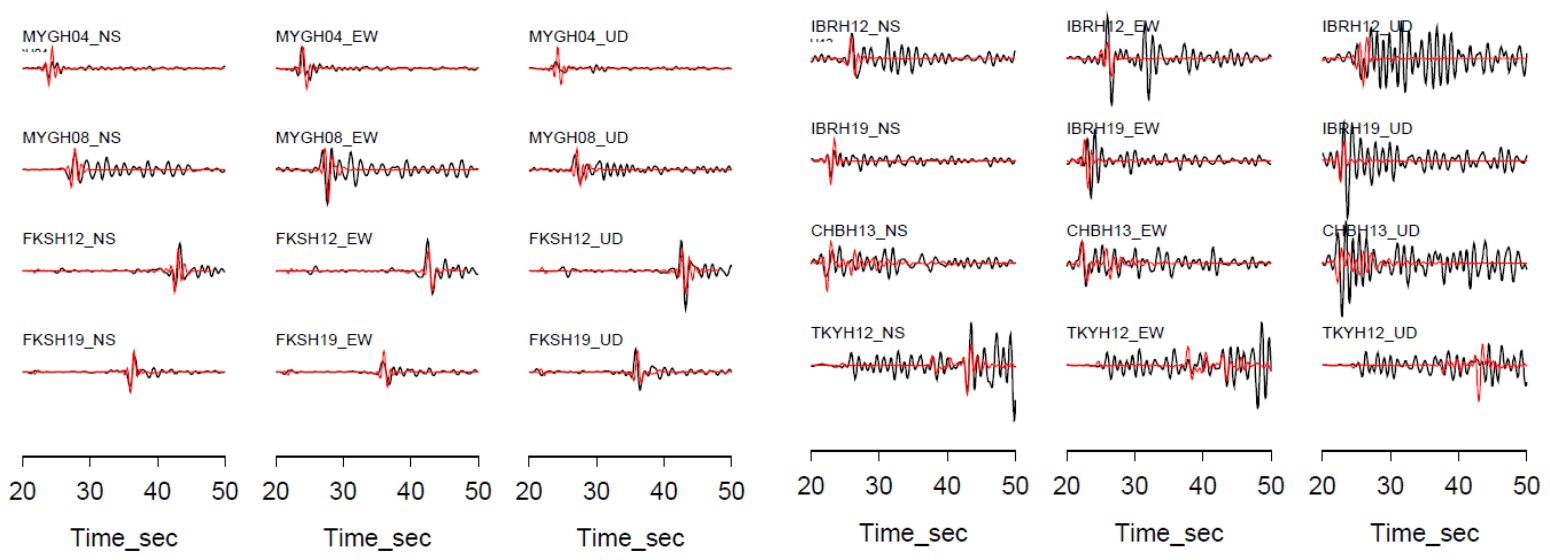

図11 全観測点の観測波形（黒）と速度構造モデルの同定結果から計算された波形（赤）を示す.
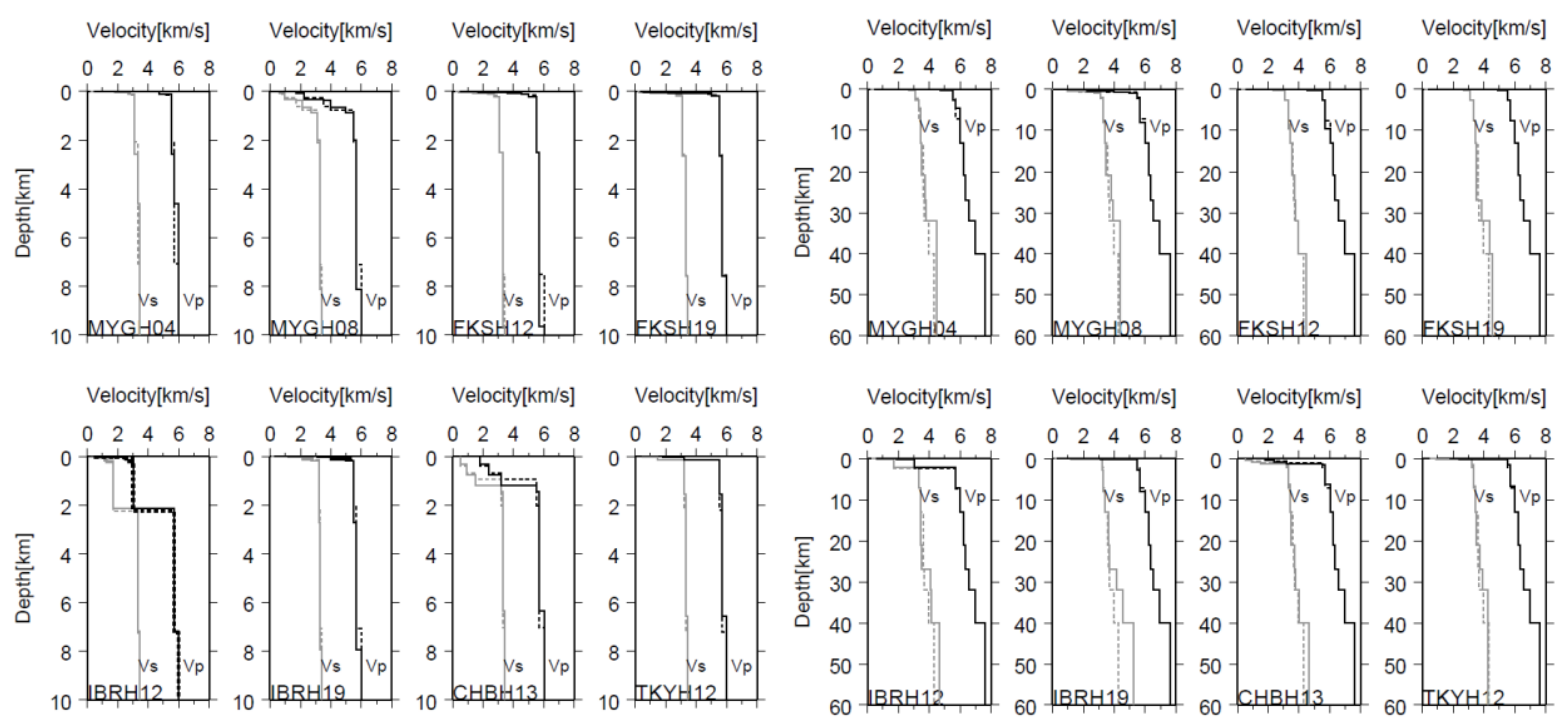

図12 初期速度構造モデル（点線）と同定した速度構造モデル（実線）の比較. 左図は, 各観測点にお ける深さ0〜10 kmまでの地盤構造モデル． 右図は，深さ0６0kmまでの地盤構造モデルを示す． 


\section{2 2011年東北地方太平洋沖地震の長周期地震動シミュレーション}

小地震を用いた地盤構造の同定モデルを利用して，2011年東北地震の長周期地震動シミュレーション を実施した. SMGA震源モデルはKurahashi and Irikura9)を用いた。なお，ここでの解析では，破壊伝播速 度士10\%の摇らぎを与えた．図13，図14，図15には， smoothed ramp関数を利用し，小断層サイズを $8.5 \mathrm{~km}$ とした場合の観測波形とシミュレーション波形の比較および観測速度フーリエスペクトルとシミュレー ション波形の速度フーリエスペクトルの比較，観測速度応答スペクトルとシミュレーション波形の速度 応答スペクトルの比較を示寸，なお，SMGA5は，Kurahashi and Irikura ${ }^{9}$ に沿って小断層サイズは $4.4 \mathrm{~km}$ している. また, 図16, 図17, 図18には, 中村・宮武のすべり速度関数を利用し, 小断層サイズ $1.0 \mathrm{~km}$ とした場合の観測波形とシミュレーション波形の比較および観測速度フーリエスペクトルとシミュレー ション波形の速度フーリエスペクトルの比較，観測速度応答スペクトルとシミュレーション波形の速度 応答スペクトルの比較を示す.

波形やスペクトルの比較結果の議論は後述するが，大局的には, smoothed ramp関数を利用した場合で も中村・宮武の関数を利用した場合でも，小断層サイズを変えることで，観測波形を概ね再現するシミ ユレーション波形を計算することができることが示された.

図13, 図16の観測波形にみられる特徴的な波群とシミュレーション波形の主要動の位相および振幅は 概ね一致していることがわかる．特に，宮城県の観測点（MYGH04とMYGH08）における観測波形とシ ミュレーション波形では，50秒付近にみられるWP1および110秒付近にみられるWP3がよく再現されて いることがわかる，一方で，茨城県の観測点（IBRH12とIBRH19）では，WP5に起因する波形の位相と 振幅についても概敞一致している.

観測速度応答スペクトルとシミュレーション波形の速度応答スペクトルについても, 宮城県や茨城県 の観測点については，概初再現できている，一方で，千葉や東京にあたる関東南部地域については，観 測に合う傾向にあるが，宮城県や茨城県の波形の一致度と比較すると観測波形との合いが良くない．宮 城県や茨城県と比較すると震源がより遠い場所となり，地盤構造モデルの精度の影響と考えられる。

また，FKSH19，IBRH12について，図13や図16の約150秒付近のWP5の部分におけるNS成分の再現性 はよいが，EW成分とUD成分については，シミュレーションの結果が観測よりも2 3倍程度過大評価と なっている. 水平成分の振幅比に影響を与えるものとしては，断層のすべり角の違いによるS波の放射 特性，3次元地下構造による伝播経路特性の影響が考えられる. さらに，加藤・他 ${ }^{32}$ で指摘されている水 平成層構造による強震動シミュレーションでは, 短周期のみならず周期 1 秒 数秒程度の周期帯域におい ても理論放射特性の影響が強くですぎる指摘もあるため，より観測記録の再現性を高めるためには，今 後これらの詳細な検討が必要である.

本地震の速度フーリエスペクトルの形状で特徴的なのは, 本研究で評価の対象としている2秒から 10 秒までの地震動周期の間に特徵的なピークが見られないことである. 寸なわち, 短周期から長周期の波 がまんべんなく含まれたパルス的な記録であったといえる.

図13と図16における smoothed ramp関数を利用したシミュレーション波形と中村・宮武の関数を利用し たシミュレーション波形の違いは, 関東地域の観測点での結果にみられ, smoothed ramp関数を用いた計 算結果は，IBRH12やTKYH12の150秒付近の波形（WS5の寄与）で高周波が卓越するような波形となっ ている．この原因は，smoothed ramp関数を用いた計算では，小断層サイズを4.4km（SMGA5）用いてお り, ランダムsummationの影響により周期範囲が広いためである.一方の中村・宮武の関数を利用した小 断層サイズ $(1 \mathrm{~km})$ の場合, 高スムーズな破壊が再現されることにより波形が平滑化される. すなわち, SMGAと破壞開始点と観測点との位置的な関係により，計算波形に影響を与える場合があるといえる. この高周波の周期帯域は，図14の観測速度フーリエスペクトルとシミュレーションの速度フーリエスペ クトルから $0.4 \mathrm{~Hz}$ 程度とみられる。

図19には，1Hz以下のローパスフィルターを施した観測速度フーリエスペクトルと smoothed ramp関数 を用いたシミュレーション波形の速度フーリエスペクトルの比較を示す. 結果を比べると, $0.05 \mathrm{~Hz}$ 以上 では，観測フーリエスペクトルとシミュレーション波形のフーリエスペクトルはよく一致しているが， $0.05 \mathrm{~Hz}$ 付近から低周波数域すなわち20秒より長周期数域になると, シミュレーション波形のフーリエス ペクトルが観測のフーリエスペクトルも大きく下回る，その理由として，観測記録は，破壊域全体から 放出された波すべてを含んでいるが，シミュレーション波形は, SMGA領域からの地震動のみ評価して 
いることにある．そして，0.05 Hz以下の低周波数の波（20秒以上の長周期の波）がSMGA以外から生成 されているためである.
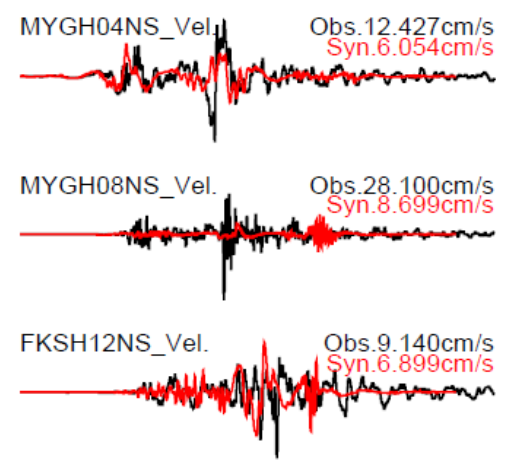

FKSH19NS_Vel.

Obs. $4.171 \mathrm{~cm} / \mathrm{s}$

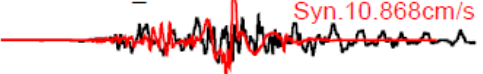

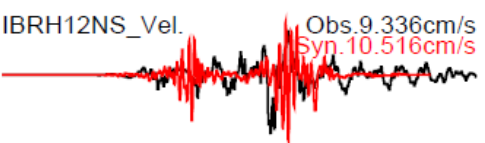

IBRH19NS_Vel.
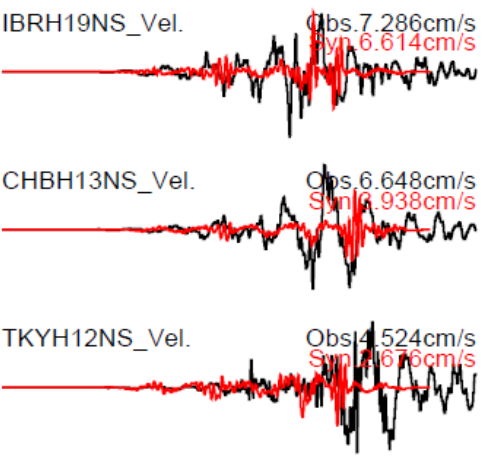
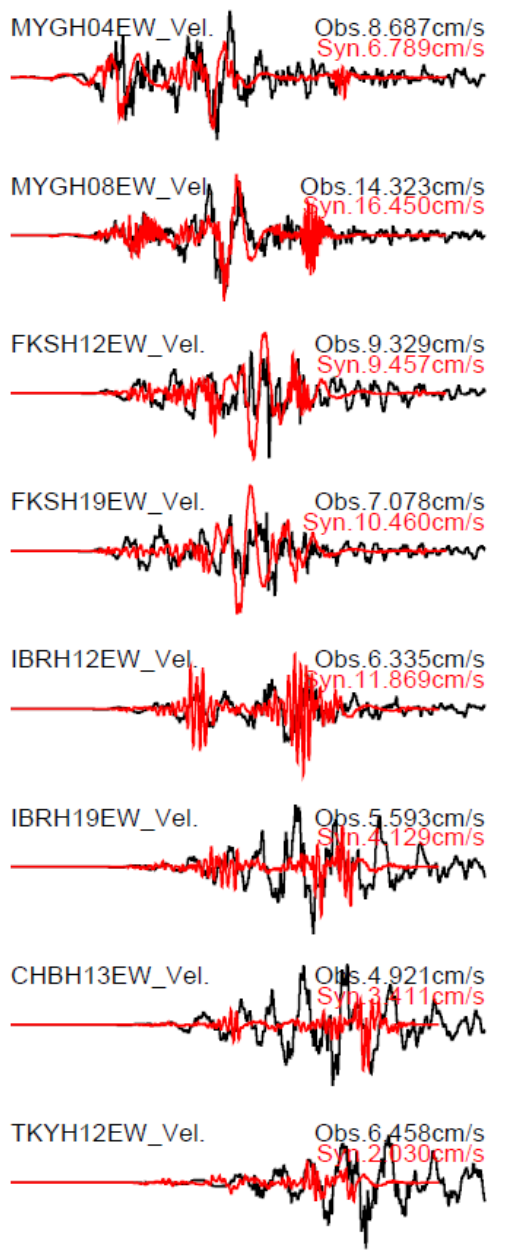
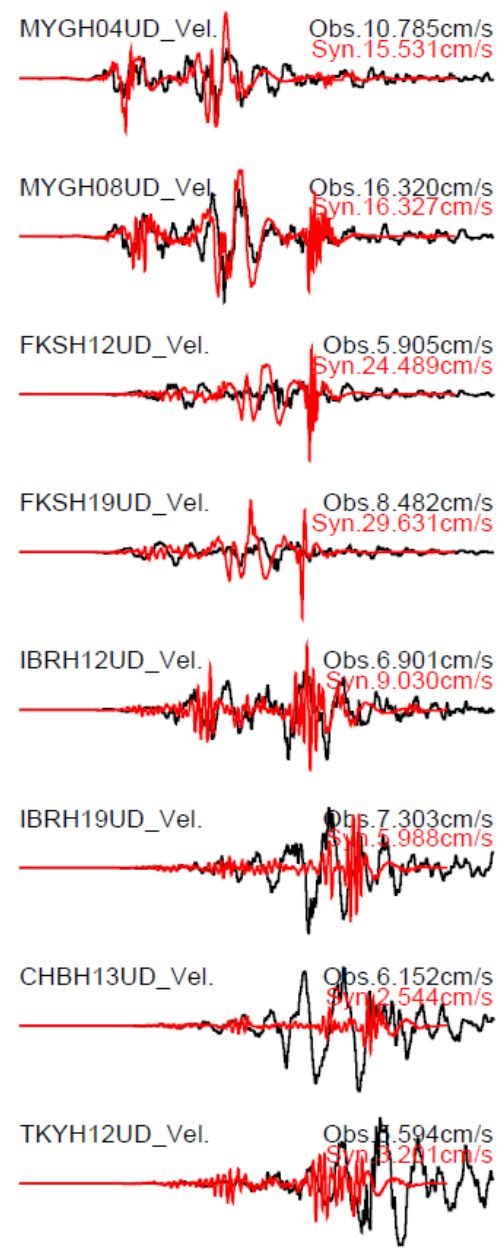

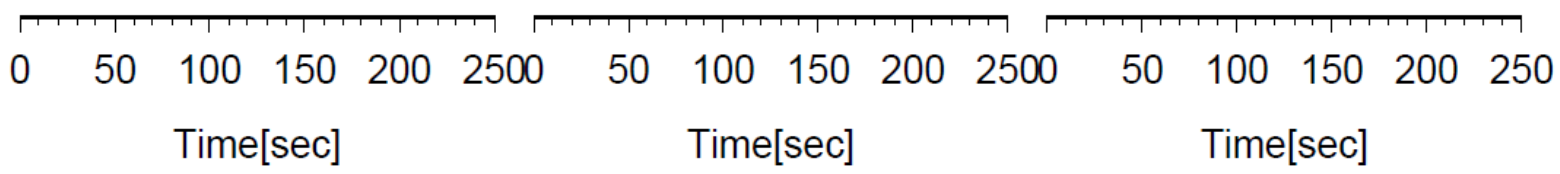

図13 Smoothed ramp 関数を利用し，小断層サイズは8. $5 \mathrm{~km}$ した場合の2011年東北地震の観測波形 (黒) と地震動シミュレーション波形（赤）との比較. (バンドパスフィルター:0.05 0. $5 \mathrm{~Hz}$ (周期2 20秒)) 


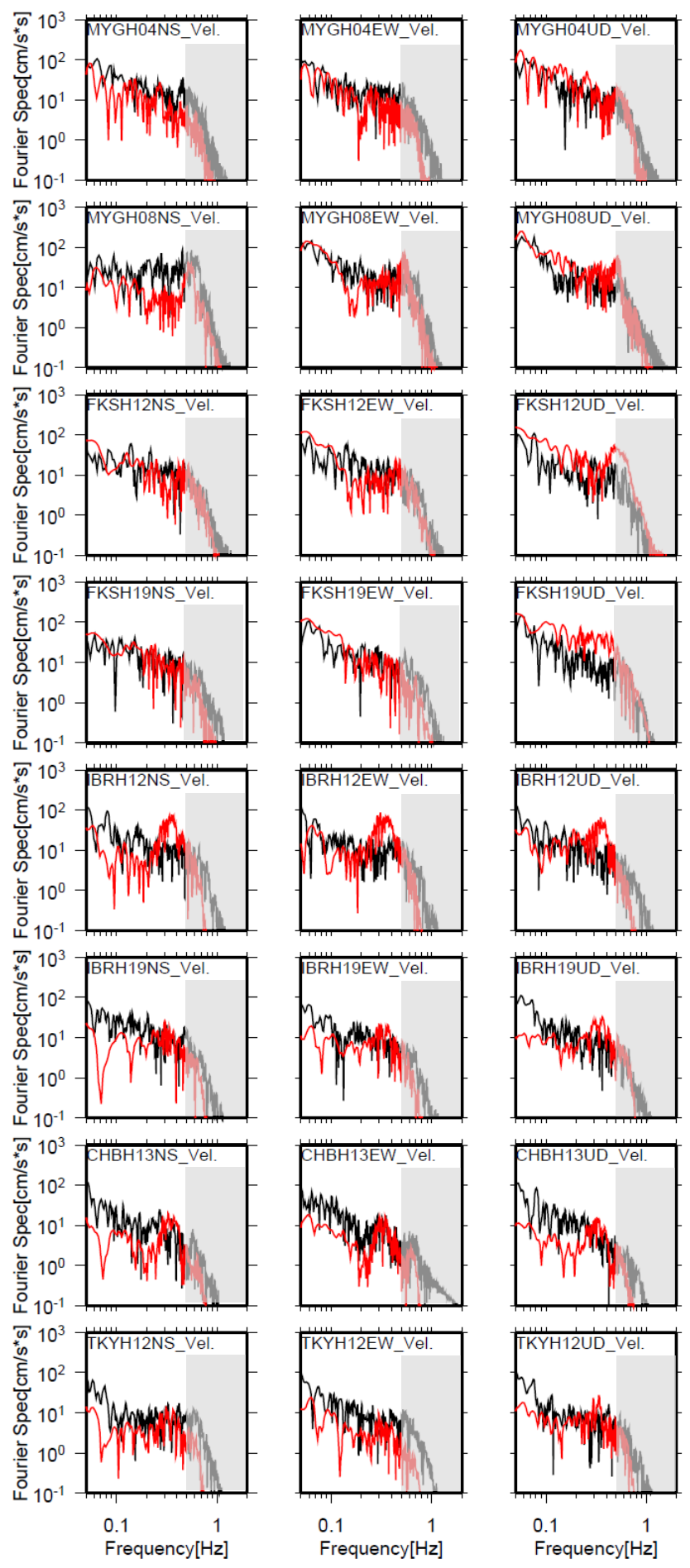

図14 観測波形の速度フーリエスペクトルと地震動シミュレーション波形の速度フーリエスペクトルの 比較. 黒線は観測波形，赤線は地震動シミュレーション波形。（バンドパスフィルター：0.05 0.5Hz (周期2 20秒）） 

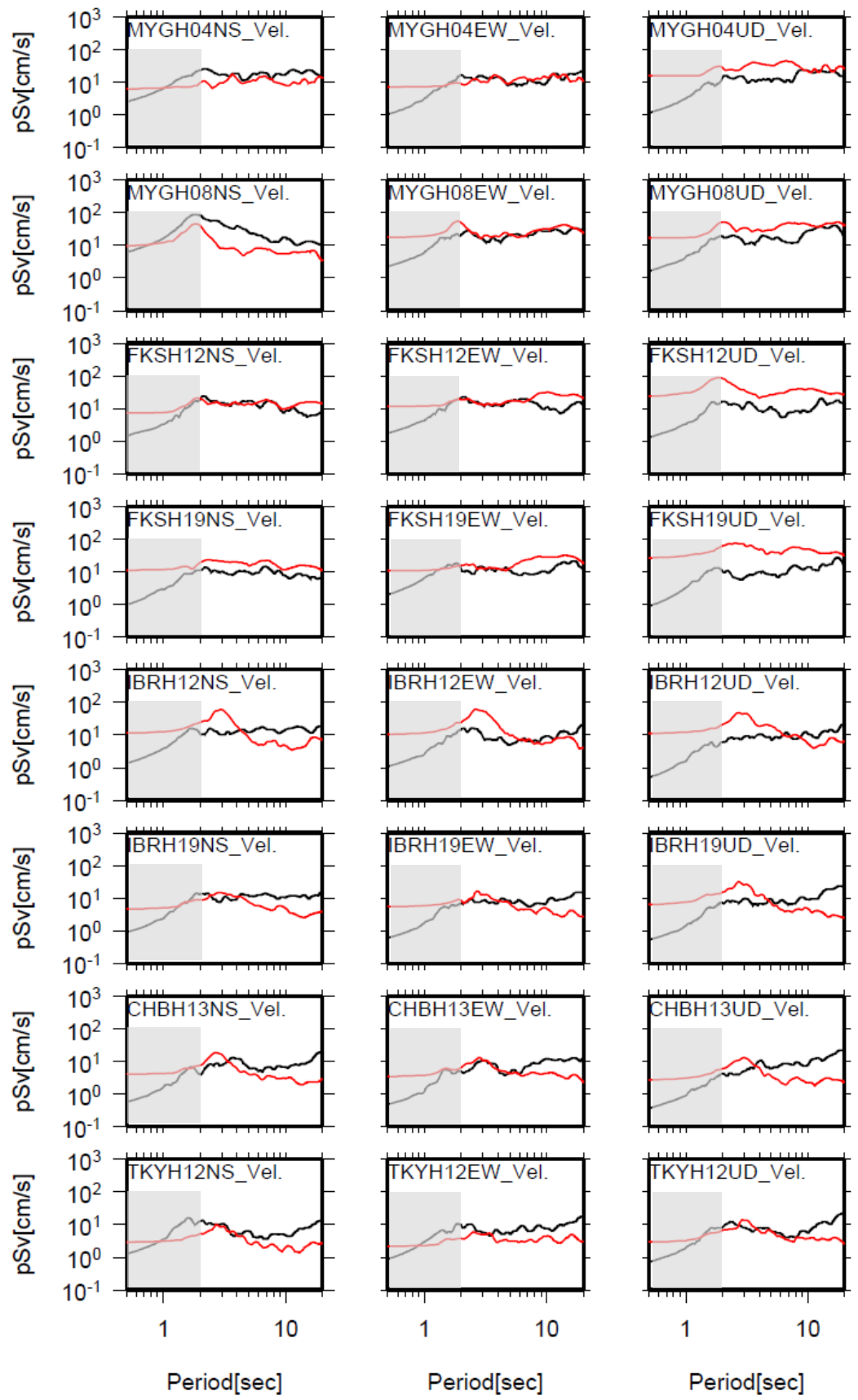

図15 観測波形の速度応答スペクトルと地震動シミュレーション波形の速度応答スペクトルの比較. 黒 線は観測波形，赤線は地震動シミュレーション波形。（バンドパスフィルター：0.05〜0.5Hz（周期2〜 20秒）） 

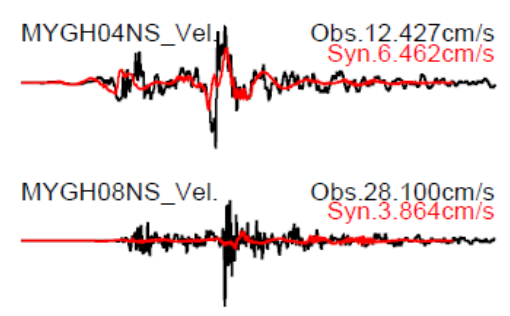

FKSH12NS_Vel.

Obs. $9.140 \mathrm{~cm} / \mathrm{s}$

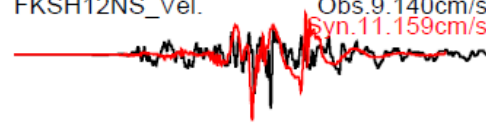

FKSH19NS_Vel.

Obs. $4.171 \mathrm{~cm} / \mathrm{s}$

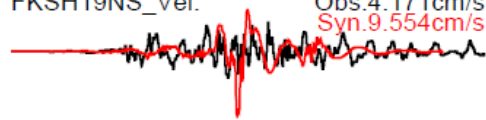
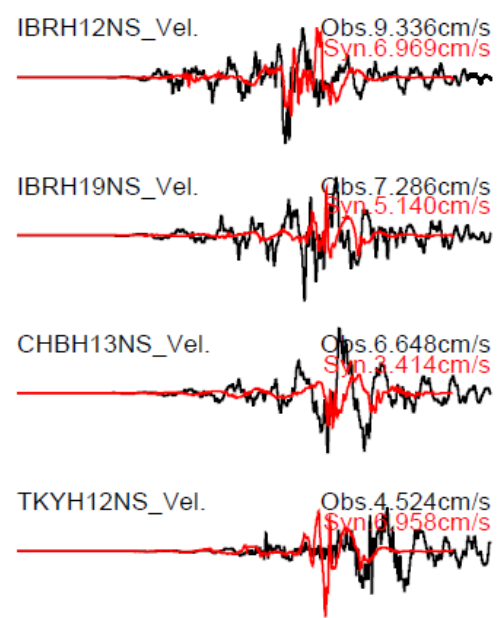

$0 \quad 50 \quad 100 \quad 150 \quad 200 \quad 2500$

Time[sec]
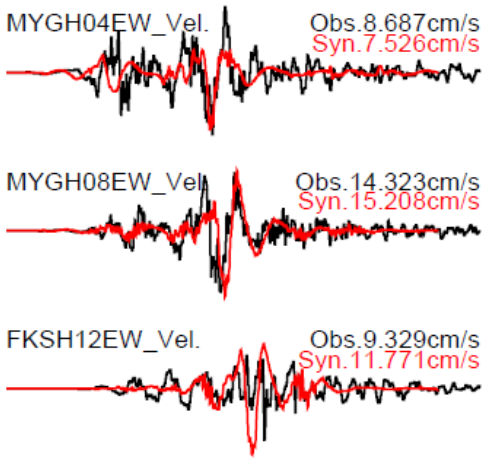

FKSH19EW Vel Obs $7078 \mathrm{~cm} / \mathrm{s}$
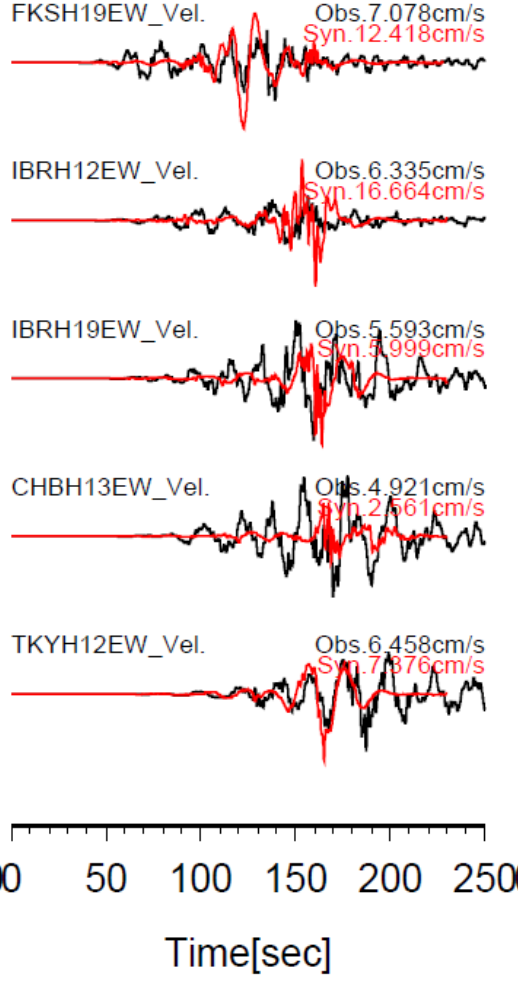
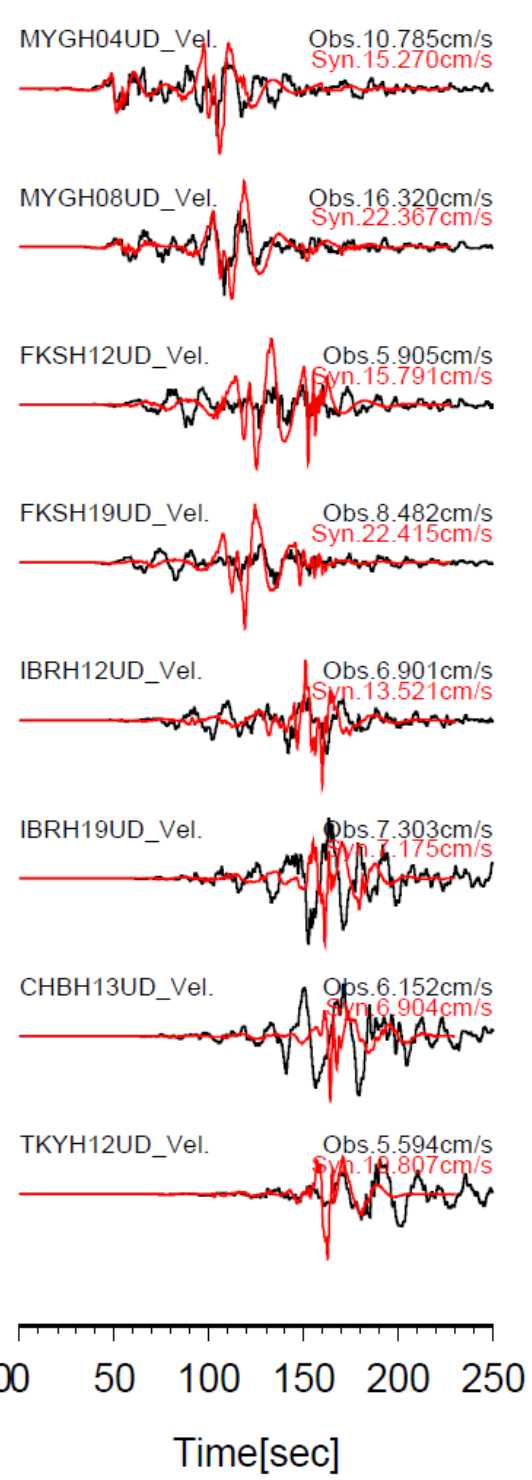

図16 中村・宮武の関数を利用し，小断層サイズは1.0kmとした場合の2011年東北地震の観測波形（黒） と地震動シミュレーション波形（赤）との比較. (バンドパスフィルター:0.05 0. $5 \mathrm{~Hz}$ (周期2 20秒)) 

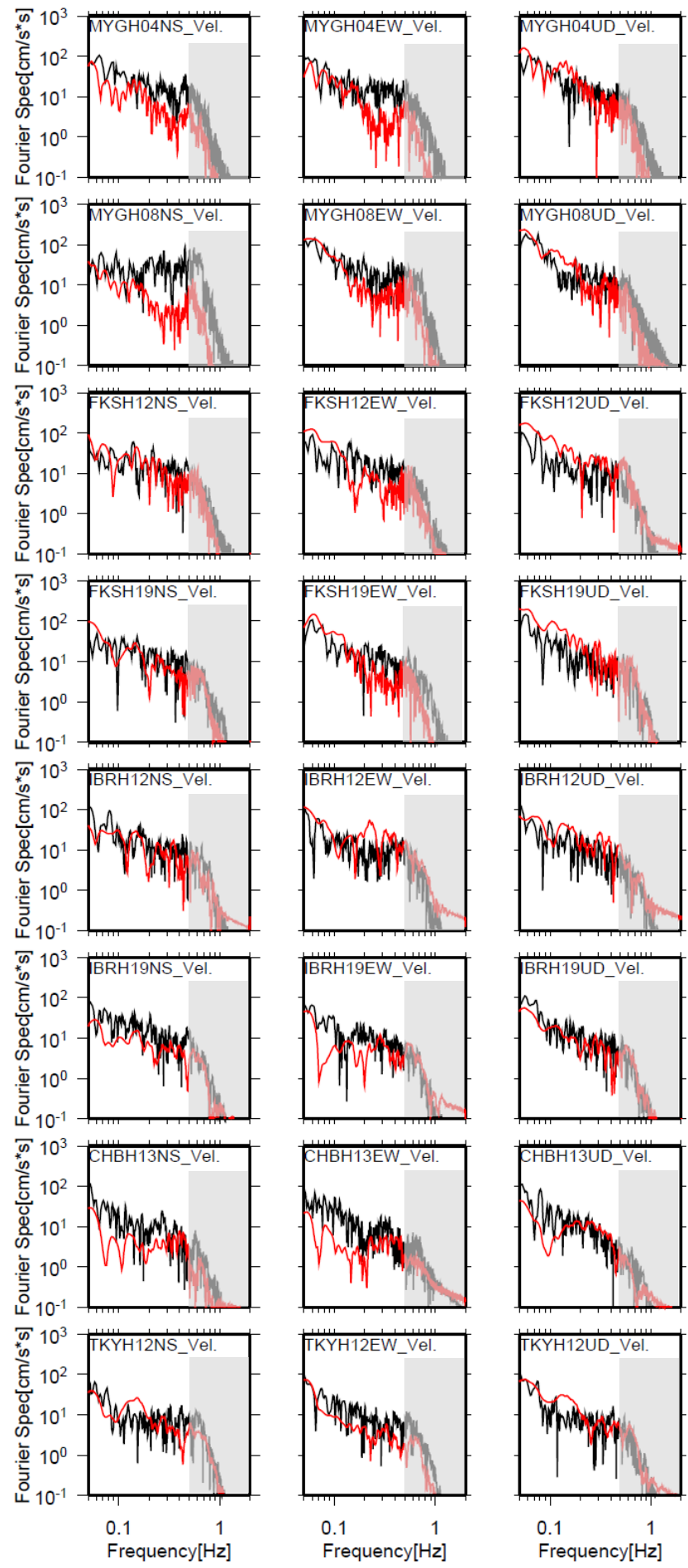

図17 観測波形の速度フーリエスペクトルと地震動シミュレーション波形の速度フーリエスペクトルの 比較. 黒線は観測波形，赤線は地震動シミュレーション波形。（バンドパスフィルター：0.05 0.5Hz (周期2 20秒）） 

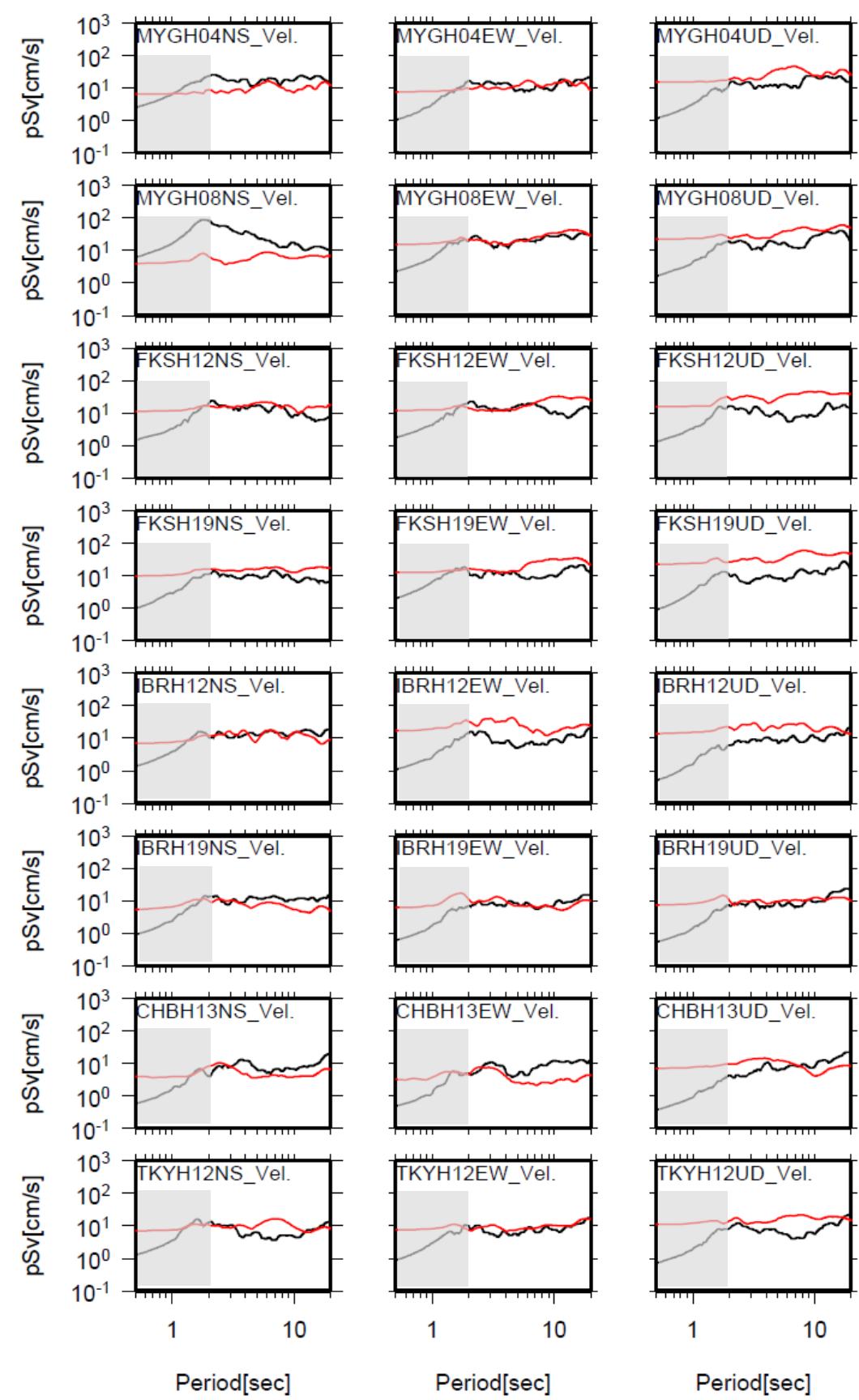

図18 観測波形の速度応答スペクトルと地震動シミュレーション波形の速度応答スペクトルの比較. 黒 線は観測波形，赤線は地震動シミュレーション波形.

（バンドパスフィルター：0.05〜0.5H（周期2〜20秒））。 

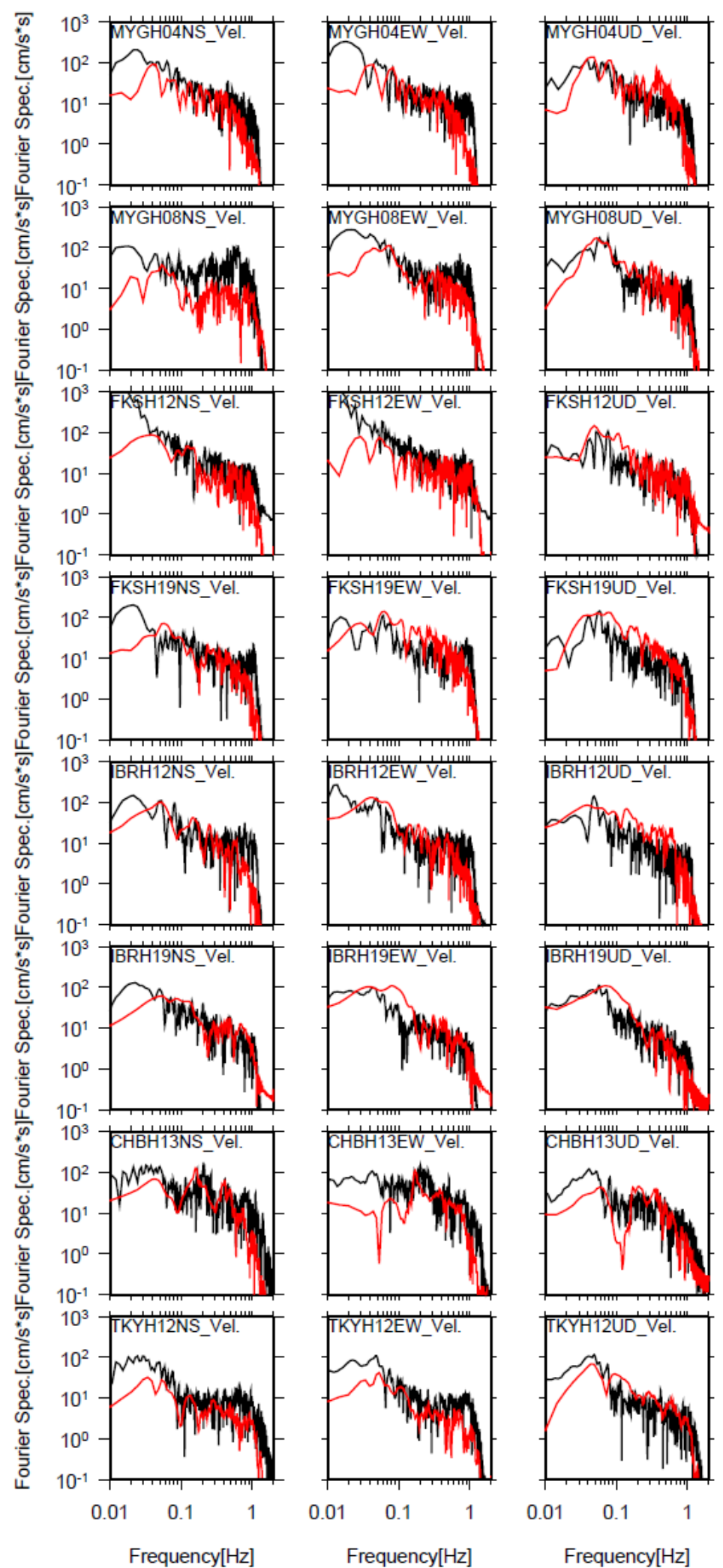

図19 観測速度フーリエスペクトル（黒）とシミュレーション波形の速度フーリエスペクトル（赤）と の比較.（ローパスフィルター: 〜 1. OHz) 


\section{5. まとめ}

本論文では，2011年東北地震の長周期強震動（2－10 秒）を再現するためのSMGA震源モデルと，こ れを用いた長周期地震動の波形合成について検討を行った。 その結果，以下のことがわかった.

1) Kurahashi and Irikura ${ }^{9}$ による2011年東北地震の震源近傍で観測された5つの波群に対応するSMGAか らの地震動の震源スペクトルは周期 2 - 10秒の周期帯域を含んでおり, SMGAの直径に対応するコーナ 一周期を持つ $\omega^{-2}$ 則に従う特性を持つ.

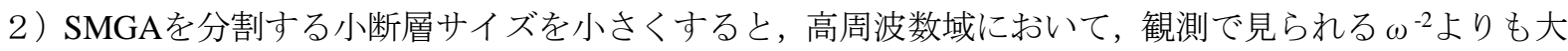
きく減衰し，対象とする 2 - 10秒の地震動が再現できない. 再現させるためには, 使用するすべり速度関 数と小断層サイズを適切に選択する必要がある.

3 ）小断層に, smoothed ramp関数を与えた場合は, 中村・宮武の関数に比べて, 高周波数域でより大き く減衰し, 小断層サイズが $8.5 \mathrm{~km}$ の場合は高周波数でほぼ $\omega^{-2} て ゙$ 減少する. 一方, 中村・宮武の関数では, 小断層サイズを $1 \mathrm{~km}$ にすると，ほぼ $\omega^{-2}$ とるが，それでも若干 $\omega^{-2}$ より大きく減衰する，その解決 方法として, 破壞伝播速度に摇らぎを与えると, 摇らぎが大きいほど高周波側で減衰傾向が小さくなる. 合成波形のスペクトルの高周波が減少しすぎることをさけるために，破壊伝播速度に摇らぎを与えるこ とが有効である.

4) 本地震による長周期地震動評価の最適モデルは, SMGAを $1 \times 1 \mathrm{~km}$ の小断層に分割し，すべり速度関 数として中村・宮武の関数を用い，破壊伝播速度に $10 \%$ の摇らぎを与えるものである. このモデルによ り，（2-10 秒）の周期帯域でほぼ $\omega^{-2}$ の特性をもつ合成波形が得られた.

5 ) SMGA震源モデルにより計算されたシミュレーション結果は, 観測スペクトルと比較すると, 周期 10秒までは良く再現できたが，それより長周期域では，観測スペクトルの方が大きくなる．これは，周 期10秒を超える長周期成分はSMGAのみではなく大すべり域や背景領域からも生成されたことを意味す る.

\section{謝 辞}

観測記録は，独立行政法人防災科学技術研究所のKiK-net記録を利用させていただきました。また，震 源の諸元情報については, 気象庁およびF-netを利用させていただきました。一部の図の作成にはGMT ${ }^{33)}$ を利用させていただきました。記して御礼申し上げます。

\section{参考文献}

1) Suzuki, W., S. Aoi, H. Sekiguchi, and T. Kunugi : Rupture process of the 2011 Tohoku-Oki mega-thrust earthquake (M9.0) inverted from strong-motion data, Geophys. Res. Lett., Vol.38, L00G16, doi:10.1029/2011GL049136, 2011.

2) Yagi, Y. and Y. Fukahata : Rupture process of the 2011 Tohoku-oki earthquake and absolute elastic strain release, Geophys. Res. Lett., Vol.38, L19307, doi:10.1029/2011GL048701, 2011.

3) 山中佳子：NGY地震学ノート No.36改訂版, 2011,

http://www.seis.nagoya-u.ac.jp/sanchu/Seismo_Note/2011/NGY36n.html (参照 2011-4-3).

4) Ozawa, S., T. Nishimura, H. Suito, T. Kobayashi, M. Tobita, and T. Imakiire : Coseismic and post-seismic slip of the 2011 Mw 9.0 Tohoku-Oki earthquake, Nature 475, pp.373-376, 2011.

5) Fujii, Y., K. Satake, S. Sakai, M. Shinohara, and T. Kanazawa : Tsunami source of the 2011 off the Pacific coast of Tohoku Earthquake, Earth Planets Space, Vol.63, pp.815-820, 2011.

6) Lee, S. J., B. S. Huang, M. Ando, H. C. Chiu, and J. H. Wang : Evidence of large scale repeating slip during the 2011 Tohoku-Oki earthquake, Geophys. Res. Lett., Vol.38, L19306, 2011.

7) Yokota, Y., K. Koketsu, Y. Fujii, K. Satake, S. Sakai, M. Shinohara, and T. Kanazawa : Joint inversion of strong motion, teleseismic, geodetic, and tsunami datasets for the rupture process of the 2011 Tohoku earthquake, Geophys. Res. Lett. Vol.38, L00G21, doi:10.1029/2011GL050098, 2011.

8) 久保久彦, 岩田知孝, 浅野公之, 青井真 : 東北日本における巨大プレート境界型地震の地震波放射特 
性の空間変化一2011年東北沖地震及び2011年茨城県沖地震の事例から一, 日本地球惑星科学連合 2015年 大会， 2015 .

9) Kurahashi, S. and K. Irikura : Short-Period Source Model of the $2011 \mathrm{Mw} 9.0$ Off the Pacific Coast of Tohoku Earthquake, Bull. Seism. Soc. Am., Vol.103, doi:10.1785/0120120157, pp.1373-1393, 2013.

10) Kurahashi, S., and K. Irikura : Source model for generating strong ground motions during the $2011 \mathrm{Off}$ the Pacific Coast of Tohoku earthquake, Earth Planets Space, Vol.63, pp.571-576, 2012.

11) 佐藤智美 : 経験的グリーン関数法に基づく2011年東北地方太平洋沖地震の震源モデル : -プレート境 界地震の短周期レベルに着目して-, 日本建築学会構造系論文集, 第77巻, 第675号, pp.695-704， 2012. 12）川辺秀憲，釜江克宏：2011年東北地方太平洋沖地震の震源のモデル化，日本地震工学会論文集，第 13巻，第2号（特集号）, pp.75-87，2013.

13) Asano, K. and T. Iwata : Source model for strong ground motion generation in the frequency range $0.1-10 \mathrm{~Hz}$ during the 2011 Tohoku earthquake, Earth Planets Space, Vol.64, pp.1111-1123, 2012.

14）川辺秀憲，釜江克宏，上林宏敏 : 2011年東北地方太平洋沖地震（M9.0）の強震動の検証と広域長周 期地震動シミュレーション，第41回地盤震動シンポジウム（2013），pp.3-10， 2013.

15) Irikura, K. : Prediction of strong acceleration motions using empirical Green's function, in Proc. 7th Japan Earthq. Eng. Symp., Tokyo, 10-12 December, pp.151-156, 1986.

16) Irikura, K. and H. Miyake : Recipe for predicting strong ground motion from crustal earthquake scenarios, Pure Appl. Geophys., Vol.168, doi:10.1007/s00024-010-0150-9, pp.85-104, 2011.

17）池田隆明，釜江克宏，入倉孝次郎：経験的グリーン関数法を用いた震源のモデル化と地盤非線形性 を考慮した地震動評価 2005年福岡県西方沖の地震と2007年能登半島地震への適用，日本建築学会構造 系論文集，第76巻，第665号，pp.153-1261，2011.

18) Kamae, K. and H. Kawabe : Source model composed of asperities for the 2003 Tokachi-oki, Japan, earthquake ( $\mathrm{M}_{\mathrm{JMA}}=8.0$ ) estimated by the empirical Green's function method, Earth Planets Space, Vol.56, pp.323-327, 2004.

19) Suzuki, W. and T. Iwata : Source model of the 2005 Miyagi-Oki, Japan, earthquake estimated from broadband strong motions, Earth Planets Space, Vol.59, pp.1155-1171, 2007.

20) Miyake, H. and K. Koketsu: Testing the Double Corner Source Spectral Model for Long- and Short-Period Ground Motion Simulations, American Geophysical Union, Fall Meeting 2010, abstract \#S53D-05, 2010.

21) 佐藤智美 : 中小地震の応力降下量の断層タイプ・震源深さ依存性及び地域性に関する研究, 土木学 会地震工学論文集, 第27巻, pp.1-8, 2003.

22) Brune, J. N. : Tectonic stress and the spectra of seismic shear waves from earthquakes, J. Geophys. Res.

Vol.75, pp.4997-5009, 1970.

23) Brune, J. N. : Correction, J. Geophys. Res. Vol.76, pp.5002, 1971.

24）赤澤隆士，入倉孝次郎：KiK-net地中観測記録を利用した震源特性・伝播経路特性評価手法の構築, 日本建築学会構造系論文集，第80巻，第708号，pp.231-240， 2015.

25) 中村洋光，宮武隆：断層近傍強震動シミュレーションのための滑り速度時間関数の近似式，地震 2 , 第53巻, pp.1-9, 2000.

26) Irikura, K. and K. Kamae : Estimation of strong ground motion in broad-frequency band based on a seismic source scaling model and an empirical Green's function technique, Annali di Geofisica, Vol.37, pp.1721-1743, 1994.

27) Hisada, T. : A Theoretical Omega-Square Model Considering Spatial Variation in Slip and Rupture Velocity.

Part 2. Case for a Two-Dimensional Source Model, Bull. Seism. Soc. Am., Vol.91, No.4, pp.651-666, 2001.

28) Bouchon, M.: A simple method to calculate Green's function for elastic layered media, Bull. Seism. Soc. Am., Vol.71, pp.959-971, 1981.

29) Kennett, B. L.N. and Kerry, N. J. : Seismic waves in a stratified half space, Geophys. J. Roy. Astr. Soc., Vol.57, pp.557-583, 1979.

30) 藤原広行, 河合伸一, 青井真, 森川信之, 先名重樹, 工藤暢章, 大井昌弘, はお憲生, 早川讓, 遠 山信彦，松山尚典，岩本鋼司，鈴木晴彦，劉瑛：強震動評価のための全国深部地盤構造モデル作成手法 の検討，防災科学技術研究所研究資料 第337号，2009. 
31) Wu, C., K. Koketsu and H. Miyake : Source processes of the 1978 and 2005 Miyagi-oki, Japan, earthquakes: Repeated rupture of asperities over successive large earthquakes, J. Geophys. Res., Vol. 113, B0816, doi:10.1029/2007JB005189, 2008.

32) 加藤研一, 久田嘉章，眞鍋俊平，野津厚，野畑有秀，森川淳，大野晋，山本優 : 統計的グリーン関 数法に基づく2004年紀伊半島南東沖地震の強震波形のベンチマークテスト，第14回日本地震工学シンポ ジウム，GO15-Fri-3，2014.

33) Wessel, P. and Smith, W.H.F. : New, improved version of Generic Mapping Tools released, EOS, AGU, 1998

\title{
Long-Period Ground Motions from Strong Motion Generation Area during the 2011 Mw 9.0 the Pacific Coast of Tohoku Earthquake
}

\author{
KURAHASHI Susumu ${ }^{1)}$ and IRIKURA Kojiro ${ }^{2)}$
}

1) Member, Visiting Lecture, Aichi Institute of Technology Disaster Prevention Research Center (Previous post) Lecture, Aichi Institute of Technology, (Current Post), Dr. Eng.

2) Member, Visiting Professor, Aichi Institute of Technology Disaster Prevention Research Center, Dr. Sci.

\begin{abstract}
This study is aiming to construct source model for simulating long-period motions (2 - 10 seconds) that cause damage of long-period structures (e.g. Skyscrapers, and large petroleum storage tanks) for mega-thrust subduction earthquakes. The large slip area caused catastrophic tsunamis was located on the shallow area near the Japan trench during the 2011 Tohoku earthquake. On the other hand, the strong motion generation area (SMGA) generating the strong motions were located west of the hypocenter and along the down-dip edge of the source fault. We clarified that ground motions from the SMGAs have the omega-squared spectral characteristics including long-periods from 2 to $10 \mathrm{~s}$ of engineering interest, analyzing the observed records identified as wavepackets from the SMGAs Then, we propose a method of evaluating the long-period ground motions from the SMGAs using an appropriate subfault size and slip velocity time functions to be able to follow the omega-square scaling model.
\end{abstract}

Keywords: 2011 the Pacific Coast of Tohoku earthquake, long-period strong motion, strong motion generation area 